\title{
Alteration in the expression of microRNA-21 regulated target genes: Role in breast cancer
}

\author{
PriYanka THAKUR ${ }^{1}$; ReEna V. SAINI ${ }^{2,3, *}$; AnIL K. CHHILlaR ${ }^{4}$; NeERAj K. SAINI ${ }^{5}$; VIJAY Kumar THAKUR ${ }^{6}$; \\ SAMARJEet SINGH SIWAL ${ }^{7}$; Adesh K. SAINI ${ }^{2,3, *}$ \\ ${ }^{1}$ Faculty of Sciences, Shoolini University, Solan, 173229, India \\ 2 Department of Biotechnology, MMEC, Maharishi Markandeshwar (Deemed to be University), Ambala, 133207, India \\ ${ }^{3}$ Maharishi Markandeshwar University, Solan, 173229, India \\ ${ }^{4}$ Centre of Biotechnology, Maharshi Dayanand University, Rohtak, 124001, India \\ ${ }^{5}$ School of Biotechnology, Jawaharlal Nehu University, New Delhi, 110067, India \\ ${ }^{6}$ Biorefining and Advanced Materials Research Center, Scotland's Rural College (SRUC), Edinburgh, EH9 3JG, UK \\ ${ }^{7}$ Department of Chemistry, MMEC, Maharishi Markandeshwar (Deemed to be University), Ambala, 133207, India
}

Key words: Non-coding RNA, microRNAs, Breast cancer, Tumor suppression, Biomarker

\begin{abstract}
Breast cancer, also recognized as the principal cause of cancer-related deaths among women, is the second most familiar and prevalent form of cancer. New diagnostic and prognostic biomarkers that are highly specific are urgently needed for its early prognosis. MicroRNAs (miRNAs), a class of non-coding RNAs, are known to control the biological processes involving transcription, post-transcriptional and covalent modifications, splicing, translation, cell differentiation, proliferation, apoptosis, cancer progression, and invasion. Any dysregulation in miRNA expression, demonstrating their oncogenic and tumor-suppressive functions, contributes to cancer progression. MicroRNA-21 (miR-21), an 'onco-miR' in breast cancer, is involved in tumor progression and metastasis by suppressing the activity of the target gene via its interaction with the 3'UTR of the target gene. The upregulation of miR-21 is observed in many instances of breast cancer. Our review aims to summarize the current understanding of miR-21 in the regulation of important cellular functions via regulation of its target genes. We discuss its biosynthesis, oncogenic function in breast cancer, and different methods used for its detection. This will increase the current understanding of the role of miR-21 in breast cancer tumorigenesis, which will offer a perception of using miR-21 as an early detection molecular prognostic and diagnostic biomarker and as a therapeutic target in breast cancer care.
\end{abstract}

\begin{tabular}{ll} 
Abbreviations & \\
Her2: & Human epidermal growth factor receptor 2 \\
ncRNAs: & Noncoding RNAs \\
miRNAs: & MicroRNAs \\
piRNA: & PIWI-interacting RNAs \\
circRNAs: & Circular RNAs \\
lncRNAs: & Long noncoding RNAs \\
miR-21: & MicroRNA-21 \\
pre-miR-21: & Precursor miR-21 \\
pri-miRNA: & Primary-miRNA \\
SNP: & Single nucleotide polymorphism \\
\hline
\end{tabular}

*Address correspondence to: Adesh K. Saini, sainiade@mmumullana.org; Reena V. Saini, reenavohra10@mmumullana.org Received: 09 April 2021; Accepted: 07 June 2021
m6A: $\quad \mathrm{N}(6)$-methyladenosine

HNRNPA2/B1: Heterogeneous nuclear ribonucleoprotein A2/B1

RISC: $\quad$ RNA-induced silencing complex

AGO2: $\quad$ Argonaute 2

miRISC: $\quad$ miRNA-induced silencing complex

Dcp 1: $\quad$ Decapping protein 1

Dcp 2: $\quad$ Decapping protein 2

XRN1: $\quad$ Exoribonuclease 1

qRT-PCR: Quantitative reverse transcription polymerase chain reaction

NGS: $\quad$ Next-generation sequencing

PDCD4: $\quad$ Programmed cell death 4

TPM1: Tropomyosin-1

PTEN: $\quad$ Phosphatase and tensin homolog

MASPIN: Mammary serine protease inhibitor 
Bcl-2:

LZTFL1:

PRMT5:

OSCC:

2-DIGE:

anti-miR-21:

PIP:

FAP:

EMT:

MAPK:

\section{Introduction}

The second most complex and heterogeneous cancer which brings mortality in 45-55 years older women across the world is breast cancer (Hemmatzadeh et al., 2016; Wang et al., 2017; Becker, 2015; Quan et al., 2020; Ataollahi et al., 2015). Aging is one of the most significant recognized risk factors associated with breast cancer. However, other risk factors such as deficiency of iodine, high estrogen level, obesity, intake of alcohol, menopause, family history, physically inactive and chest radiation exposure are also involved in breast cancer (Yager and Davidson, 2006; Steiner et al., 2008; Stoddard et al., 2008; Ataollahi et al., 2015). Breast cancer occurs in tissues that include mammary glands and ducts, resulting in lumps, swelling, redness, irritation in breast skin and nipples discharge (Ataollahi et al., 2015). The breast cancer cells are categorized into six major subtypes based on their phenotype and gene expression profile, including i) luminal $\mathrm{A}$, ii) luminal B, iii) tumor enriched with human epidermal growth factor receptor 2 (also known as Her2), iv) basal-like (triple-negative), v) normal-like, and vi) claudin-low subtype (Singh and Mo, 2013; Sørlie et al., 2003; Eroles et al., 2012).

It is believed that the mortality rate due to breast cancer can be reduced through the early diagnosis and detection of these six subtypes (Imani et al., 2017). The mammographic screening tool is the most operative tool used for the early diagnosis of tissue-based tumors in the breast (Taplin et al., 2008; Imani et al., 2017). But this tool has certain limitations such as high false-positive results, low reactivity, and low preciseness and, not adequate to diagnose the subtypes, so there is a need for new diagnostic and prognostic biomarkers that are highly specific (Adhami et al., 2018; Imani et al., 2017). Various non-coding RNAs (ncRNAs) that involve microRNAs (miRNAs), PIWIinteracting RNAs (piRNA), circular RNAs (circRNAs), and long non-coding RNAs (lncRNAs) are found to regulate biological processes like transcription, post-transcriptional modifications, covalent modifications, splicing, and translation in the metastasis phase of breast cancer cells (Klinge, 2018). Of all the ncRNAs studied in breast cancer, miRNAs are the most thoroughly studied and have diagnostic potential (Lo et al., 2016).

miRNA in breast cancer

miRNAs perform a crucial function in cancer research as predictive, diagnostic and, prognostic biomarkers because of their regulatory roles in vital processes of life like cell differentiation, proliferation, apoptosis, cancer progression and invasion (Kim, 2005; O'Day and Lal, 2010; Yu and Cheah, 2017). miRNAs are 15-27 nucleotides, short endogenous ncRNA molecules that are well known for posttranscriptionally regulating gene expression in eukaryotes by base pairing with protein-coding mRNA genes 3'-UTR (Feng and Tsao, 2016; Han et al., 2016; Wilczynska and Bushell, 2015; Adhami et al., 2018). Around half of the human miRNAs are placed on human cancer-related chromosomal regions (fragile sites), enabling them to alter the tumor suppressor or oncogenic pathways (Calin et al., 2004; Hemmatzadeh et al., 2016; Tang et al., 2012; Casalini and Iorio, 2009; Croce, 2009). Various studies have shown the miRNAs involvement as oncogenic/tumor suppressor in the pathogenesis of breast cancer as defined in Tab. 1 (Zhu et al., 2008; Si et al., 2007; Yan et al., 2008; Kong et al., 2012; Hassan et al., 2012; Fabian and Sonenberg, 2012).

In breast cancer, microRNA-21 (miR-21) is the key miRNA used in the invasion process and facilitates tumor progression and metastasis (Han et al., 2012a; Han et al., 2012b). miR-21, also identified as MIR21, hsa-mir-21, miRNA21, MIRN21, is located on chromosome 17q21.3 encoding 72-nt long precursor miR-21 (pre-miR-21) (Abdel-hamid et al., 2015; Hemmatzadeh et al., 2016). By targeting multiple tumor/metastasis suppressor genes, miR21 functions as an oncogene (Abdel-hamid et al., 2015; Hemmatzadeh et al., 2016; Selcuklu et al., 2009). The upregulated expression of miRNA-21 has been correlated with lymph node metastasis, advanced tumor levels and poor prognosis; therefore, it can act as a prognostic marker in breast cancer (Yan et al., 2008; Hemmatzadeh et al., 2016; Lee et al., 2011; Li et al., 2016; Shen et al., 2015).

\section{Biosynthesis of miRNA}

In the nucleus, the RNA polymerase II transcribes non-coding miRNA gene into 100-120 nt long hair pin structured primary-miRNA (pri-miRNA) (Petri and Klinge, 2020; Lee et al., 2004; Yu and Cheah, 2017) (as shown in Fig. 1). The enzymes DROSHA (a class 2 ribonuclease III) and DGCR8 (dsRNA-binding protein) cleave the hair pin structure of pri-miRNA to produce $70 \mathrm{nt}$ pre-miRNA (Filippov et al., 2000; Gregory et al., 2004; Denli et al., 2004). DROSHA (encoded by miRNA machinery gene) is responsible for processing miRNA in the initial phase (Khan et al., 2014). The pri-miRNA is further modified by the $\mathrm{N}(6)$ methyladenosine (m6A) post-transcriptionally, stimulating the beginning of the miRNA biosynthesis process (Alarcón et al., 2015a). The heterogeneous nuclear ribonucleoprotein A2/B1 (HNRNPA2/B1) attaches to m6A in pri-miRNA, assisting DROSHA's transformation of pri-miRNA into pre-miRNA (Alarcón et al., 2015b). After trimming of pri-miRNA, Exportin 5 (encoded by XPO5) or Exportin 1 (encoded by XPO1) exports pre-miRNA to the cytoplasm for further processing by the Dicer enzyme (Sheng et al., 2018). DROSHA plays a very significant role. The single nucleotide polymorphism (SNP) located in the 3'UTR of DROSHA rs10719 has been linked to breast cancer risk because it abrogates the hsa-miR-1298 binding site in DROSHA, thus affecting its expression (Khan et al., 2014). 
TABLE 1

Oncogenic and tumor suppressor miRNAs target genes in breast cancer

\begin{tabular}{|c|c|c|}
\hline miRNA & Target Genes & Role \\
\hline \multicolumn{3}{|c|}{ Oncogenic miRNAs } \\
\hline miR-21 & $\begin{array}{l}\text { Bcl-2, PDCD4, TPM1, PTEN, } \\
\text { MASPIN, LZTFL1 }\end{array}$ & $\begin{array}{l}\text { Apoptosis; cell proliferation; } \beta \text {-cateni } \\
\text { nuclear signaling; EMT process } \\
\text { regulator }\end{array}$ \\
\hline miR-155 & $\begin{array}{l}\text { RHOA, SOX1, SOCS1, } \\
\text { MMP16, PTEN, DUSP14, } \\
\text { PIK3R1, FOXO3a, ZEB2, } \\
\text { TSPAN5 }\end{array}$ & $\begin{array}{l}\text { TGF- } \beta / \text { Smad pathway; cell } \\
\text { proliferation and migration; PIK3R1 } \\
\text { FOXO3a-cMYC pathway; cell } \\
\text { invasiveness; miR-155/TSPAN5 } \\
\text { signaling axis }\end{array}$ \\
\hline $\mathrm{miR}-373 / 520 \mathrm{c}$ & $\begin{array}{l}\text { CD44, IL-8, ESR1, TXNIP, } \\
\text { RABEP1, RELA, TGFBR2 }\end{array}$ & $\begin{array}{l}\text { Oncogene-induced p53 pathway; } \\
\text { metastasis; EMT process; pro- } \\
\text { metastatic }\end{array}$ \\
\hline miR-9 & $\begin{array}{l}\text { LIFR, E-cadherin, PTEN, } \\
\text { DUSP14, FOXO1, AR, ESR1, } \\
\text { STARD13, SOCS3, PIAS3, } \\
\text { ONECUT2 }\end{array}$ & $\begin{array}{l}\text { Cellular differentiation; Metastasis; } \\
\text { cell proliferation, migration, and } \\
\text { invasion; oestrogen regulated pathwa } \\
\text { JAK/STAT signaling pathway; } \\
\text { androgen receptor pathway; blockhe } \\
\text { EV miRNA-ONECUT2 axis }\end{array}$ \\
\hline miR-10b & $\begin{array}{l}\text { RHOC, HOXD10, MAPRE1, } \\
\text { PIEZO1, SRSF1, TP53, } \\
\text { CDKN2A, TRA2B, FUT8, } \\
\text { NR4A3, TBX5, PTEN, NF1, } \\
\text { KLF4 }\end{array}$ & $\begin{array}{l}\text { Metastasis; cell proliferation and } \\
\text { invasion; AKT signaling pathway; } \\
\text { transcriptional misregulation; pro- } \\
\text { metastatic; EMT process; adhesion } \\
\text { and migration }\end{array}$ \\
\hline
\end{tabular}

ANXA1, SPRED1, annexin-A1 Cell proliferation; estrogen signaling

References

miR-196a

$\operatorname{miR}-221 / 222$
ERa, p27 $7^{k i p 1}, p 57, P T P \mu, P T E N$, Signaling pathways (Wnt, TGF- $\beta$, p53, Rao et al., 2011; Garofalo et al., 2012; Bim, TIMP3, SOCS3, Notch3, MAPK, Notch, Erb B and Jak-STAT); Liang et al., 2018; Li et al., 2017; Liu et A20 (TNFAIP3), c-Rel, CTGF, focal adhesion; Wnt/ $\beta$-catenin al., 2018; Santolla et al., 2018; Zong et GAS5

signaling; A20/c-Rel/CTGF signaling; Akt/NF-kB/COX-2 pathway; promotes EMT process; antiapoptosis; cell proliferation

Cluster 17/20 (miR-17- AIB1, cyclin D1, STAT3, FOSL Cell proliferation by Wnt, $\beta$-Catenin; 3p, miR-17-5p, miR-18, (Fra-1), IMPDH1, NPEPL1, miR-19a, miR-19b, PTEN, BRCA2, VEZF1

LEF1 pathway; apoptosis; prometastatic; pro-angiogenesis
Tang et al., 2017; Eichelser et al., 2014; Huang et al., 2008; Yan et al., 2011; Keklikoglou et al., 2012

Ma et al., 2010; Chen et al., 2012; Kia et al., 2019; Liu et al., 2017; Moazzeni et al., 2017; Barbano et al., 2017; Li et al., 2020; Jiang et al., 2020; Bandini et al., 2020; Shen et al., 2019

Ma et al., 2007; Ma et al., 2010; Meerson et al., 2019; Guo et al., 2018; M'hamed et al., 2017; Kim et al., 2018; Kim et al., 2016; Negrini and Calin, 2008

Luthra et al., 2008; Jiang et al., 2018; Rahim et al, 2019

al., 2019; Chen et al., 2020; Tang et al., 2019

Hossain et al., 2006; He et al., 2005; Mu et al., 2019; Liao et al., 2017; Yang et al., 2013 miR-20, and miR-92)

\section{Tumor Suppressor miRNAs}

miR-206

miR-125a, b

HER2, HER3, KIAA1522, $B A P 1$

miR-34a

miR-200 neurokinin-1, WBP2 C22ORF28

BMI-1, ZEB1, ZEB2, QKI,
ESR1, NAMPT, MKL1, IL11, ER signaling; inhibition of stemness TWF1, SRF, WDR1, MRTF-A, and metastasis; cell migration and

Bcl-2, SIRT1, CCND1, CDK6, E2F3, MYC, ErbB2, Notch1, $M Y B$ progression; modulation of tamoxifen sensitivity

Anchorage-dependent growth; differentiation; cell proliferation, migration and invasion

DNA damage; cell proliferation; drug resistance; FOXM1/eEF2K signaling axis

TGF- $\beta$ signaling; EMT process; tamoxifen resistance
Iorio et al., 2005; Adams et al., 2007; Samaeekia et al., 2017; Xiang et al., 2017; Zhou et al., 2019; Hesari et al., 2018; Ren et al., 2017

Mattie et al., 2006; Scott et al., 2007; Iorio et al., 2005; Li et al., 2018; Yan et al., 2018

Li et al., 2013; Christoffersen et al., 2010; Welch et al., 2007; Sun et al., 2008; Wang et al., 2017; Li et al., 2017; Bayraktar et al., 2018; Lin et al., 2017; Rui et al., 2018

Uhlmann et al., 2010; Cochrane et al., 2010; Gregory et al., 2008; Dykxhoorn et al., 2009; Shimono et al., 2009; Kim et al., 2019; Gao et al., 2019 
Table 1 (continued).

\begin{tabular}{|c|c|c|c|}
\hline miRNA & Target Genes & Role & References \\
\hline $\operatorname{miR}-17-5 p$ & AIB1, CCND1, E2F1, STAT3 & Proliferation; apoptosis & $\begin{array}{l}\text { Hossain et al., 2006; Yu et al., 2008; } \\
\text { Liao et al., } 2017\end{array}$ \\
\hline $\operatorname{miR}-31$ & $\begin{array}{l}\text { FZD3, ITGA5, M-RIP, } \\
M M P 16, R D X, R H O A, D k k 1\end{array}$ & Metastasis; Wnt $/ \beta$-catenin & Valastyan et al., 2009; Lv et al., 2017 \\
\hline let-7 & $\begin{array}{l}\text { RAS, HMGA-2, H-RAS, LIN28, } \\
\text { PEBP1, MCY, CCND1, } \\
\text { CYP19A1, MAGE-A1, ADRB2, } \\
\text { HIFIAN, CLDN12, MZF1 }\end{array}$ & $\begin{array}{l}\text { Proliferation, differentiation; EMT } \\
\text { pathway; EMC receptor interaction; } \\
\text { pro-metastatic; angiogenesis; } \\
\text { migration and invasion }\end{array}$ & $\begin{array}{l}\text { Yu et al., 2007; Mayr et al., 2007; Wu et } \\
\text { al., 2006; Johnson et al., 2005; Song et } \\
\text { al., 2020; Qattan et al., 2017; Shibahara } \\
\text { et al., 2012; Mi et al., 2019; Du et al., } \\
\text { 2019; Tvingsholm et al., 2018 }\end{array}$ \\
\hline miR-205 & $\begin{array}{l}\text { HER3, RunX2, HMGB1- } \\
\text { RAGE, S1PR1 }\end{array}$ & $\begin{array}{l}\text { P13K/Akt pathway; regulates the } \\
\text { activity of CD } 44^{+} / \mathrm{CD} 24^{-} \text {breast cancer } \\
\text { stem cells; EMT process and cell } \\
\text { invasion }\end{array}$ & $\begin{array}{l}\text { Iorio et al., 2009; Wang et al., 2019; } \\
\text { Fang et al., } 2020\end{array}$ \\
\hline $\operatorname{miR}-30 a$ & $\begin{array}{l}\text { SNAI1, Vimentin, Notch1, } \\
\text { Snail, ROR1, Slug, TWIF1, } \\
\text { vimentin, UBE3C }\end{array}$ & $\begin{array}{l}\text { Motility and invasiveness; EMT and } \\
\text { metastasis; inhibition of cell viability } \\
\text { and migration; apoptosis }\end{array}$ & $\begin{array}{l}\text { Cheng et al., 2012; Wang et al., 2018; } \\
\text { Kawaguchi et al., 2017; Zhang et al., } \\
\text { 2017; Xiao et al., } 2019\end{array}$ \\
\hline
\end{tabular}

Dicer is a RNase III class of enzyme that cleaves the hair pin region of pre-miRNA to produce 20-30 nts of duplex miRNA composed of two single guide ( $5^{\prime}$ to $3^{\prime}$ ) and passenger (3' to 5') strands (Kobayashi and Tomari, 2016; Höck and Meister, 2008; Petri and Klinge, 2020). This guide strand joins the PAZ domain of RNA-induced silencing complex (RISC) to mediate post-transcriptional gene silencing of the target mRNA through Argonaute 2 (AGO2, RNase, catalytic part of RISC having "slicer" activity) which cleaves the target mRNA and the PIWI domain of RISC is responsible for the degradation of passenger strand (Höck and Meister, 2008; MacFarlane and Murphy, 2010; Yu and Cheah, 2017).

miRNA-induced silencing complex (miRISC, composed of $A G O 2$ and guide strand) mediate the degradation of target mRNA. miRISC follows Ago-catalyzed, decapping, deadenylation, and exonucleolytic mechanisms (Eulalio et al., 2008; Behm-Ansmant et al., 2006; Wahid et al., 2010). Once miRNA and target mRNA complement each other, AGO2's endonuclease activity is activated, cleaving the target mRNA (MacFarlane and Murphy, 2010). The miRISC inhibits the translation by obstructing the eIF4F complex, and mRNA circularization process of the target mRNA (Wahid et al., 2010). The GW182 family proteins bind to $A G O 2$ are recruited by miRISC and act as a scaffold for the complex poly(A)-deadenylase PAN2-PAN-3 and CCR4NOT proteins (MacFarlane and Murphy, 2010; O’Brien et al., 2018). The poly(A)-deadenylation process is initiated by the PAN2-PAN3 complex and completed by the CCR4NOT protein complex. This process is further enhanced through the interaction of poly(A)-binding protein (PABPC) and GW182 tryptophan (W)-repeats (MacFarlane and Murphy, 2010; O'Brien et al., 2018). The exosome (with 3'-5' exonuclease activity) mediates the degradation process and the enzymes, decapping protein 1 (Dcp 1) and decapping protein 2 (Dcp 2) facilitate the process by inducing exoribonuclease 1 (XRN1), which target 5'-3' mRNA degradation (MacFarlane and Murphy, 2010; O'Brien et al., 2018).

\section{Identifying miRNA in breast cancer cells}

miRNAs have crucial role in gene regulation, so it is becoming imperative to develop and improve methods that can detect miRNAs because their detection in breast cancer is difficult due to their small size, low abundance, high level of sequence similarities (Chandrasekaran et al., 2019; Ye et al., 2019). The most well-known traditional methods for the detection of miRNA are microarray, in situ hybridization, bead-based flow cytometry, next-generation sequencing (NGS), northern blotting, and quantitative reverse transcription polymerase chain reaction (qRT-PCR) (Ye et al., 2019; van Schooneveld et al., 2015). Out of these methods, northern blotting and in situ hybridization are low throughput methods, whereas microarray, bead-based flow cytometry, qRT-PCR and NGS are high throughput methods (van Schooneveld et al., 2015).

Northern blotting is the most standardized and highly specific method that can detect mature miRNA and their precursors (Ye et al., 2019; Várallyay et al., 2008). Besides these, the northern blotting method has a poor sensitivity and cannot detect the RNAs present in low amounts in few cells (Ye et al., 2019). qRT-PCR method is a highly sensitive and specific method used for evaluating miRNA and for the authentication of data prevailed from other detection platforms (Balcells et al., 2011; Yu and Cheah, 2017). The bead-based flow cytometry method is moderate in sensitivity and strong in specificity, whereas the in situ hybridization method is low in sensitivity and specificity (van Schooneveld et al., 2015). Microarray is a rapid method that can examine plenty of miRNAs from vast numbers of samples, with low 
sensitivity and specificity (Li and Ruan, 2009; Cissell and Deo, 2009). All these methods recognize only known miRNA structures, but NGS is the latest high sensitivity and specificity approach that enables new miRNAs to be recognized (van Schooneveld et al., 2015; Creighton et al., 2009). In the case of breast cancer, the upregulated levels of miR-21 can also be detected from tissues, blood, and serum (Yu and Cheah, 2017; Savad et al., 2012).

\section{Oncogenic role of miR-21 in breast cancer cell proliferation and metastasis}

The "oncomiR" miR-21 is believed to be involved in tumor proliferation and metastasis in breast tissues by controlling the expression of tumor suppressor genes such as programmed cell death 4 (PDCD4), tropomyosin-1 (TPM1), phosphatase and tensin homolog (PTEN), mammary serine protease inhibitor (MASPIN); an apoptosis suppressor gene, $B$-cell lymphoma 2 (Bcl-2), and leucine zipper transcription factor-like 1 gene [(LZTFL1), a tumor suppressor] (Si et al., 2007; Zhu et al., 2007; Frankel et al., 2008; Qi et al., 2009; Zhu et al., 2008; Wei et al., 2010; Wang et al., 2019) (illustrated in Fig. 2). These genes play a critical role in breast cancer and are targeted by miR- 21 .

\section{Programmed Cell Death 4 (PDCD4)}

In both immune/non-immune cells, the programmed cell death 4 gene is a tumour suppressor (Jiang et al., 2017). The PDCD4 protein contains three domains (two MA-3 domains and the $\mathrm{N}$-terminal domain) that play a role in transcription and translation inhibition (Jiang et al., 2017). Owing to the binding of its MA-3 domains to eIF4A, PDCD4 prevents the translation of mRNAs having structured 5'UTRs, hindering eIF4A binding to eIF4G, even blocking eIF4A's helicase activity, thus repressing the translation initiation mechanism of many genes, such as p53, Atg5, pro-caspase 3, and LXR- $\alpha$ (Kroczynska et al., 2012; Yang et al., 2004). By interacting with its N-terminal domain with A-myb \& c-myb (RNA secondary structures), PDCD4 represses the elongation mechanism of translation (Singh et al., 2011). PDCD4 prevents tumor cell proliferation and invasion via inducing their apoptosis, leading to its upregulation in various tumors like breast, ovarian, gastric, esophageal, lung, hepatocellular, colon and glioma tumors (Powers et al., 2011; Wei et al., 2012; Jiang et al., 2017). The protein arginine methyltransferase 5 (PRMT5) deregulates the activity of the PDCD4 gene, resulting in breast cancer cell proliferation and invasiveness (Powers et al., 2011). miR-21 has been shown to target PDCD4 in tumour cells, thereby downregulating its expression (Sheedy et al., 2010).

PDCD4 is a target of miR-21 for breast cancer (Frankel et al., 2008). The miR-21 binding sites in the PDCD4 3'UTR are shown in Fig. 3A, which shows how miR-21 interacts with the PDCD4 3'UTR. To assess the fact that miR-21 specifically targets PDCD4, the firefly luciferase reporter assay was carried out. Frankel and his colleagues first cloned PDCD4's 400-500 bp of 3'UTR into the pGL3 vector and then developed single (pGL3-PDCD4MUT1) and double (pGL3-PDCD4MUT2) mutations in the pGL3-PDCD4 seed region. PGL3-PDCD4, pGL3-PDCD4MUT1 \& pGL3PDCD4MUT2 were transfected into HEK293 cells and luciferase activity was tested after $24 \mathrm{~h}$.
Results showed that miR-21 had no effect on pGL3PDCD4MUT2 regulation but had little effect on pGL3PDCD4MUT1 regulation (as shown in Fig. 3B), leading to the inference that there is a clear association between miR21 and PDCD4 seed region 3'UTR. To verify the effects of miR-21 inhibition, they knocked down PDCD4 in MCF-7 cells via siRNA and found that PDCD4 siRNA mediated the antiproliferative effect on MCF-7 cells (see Figs. 3C, D). Thus, revealing the significance of PDCD4 by miR-21 as a putative target for breast cancer (Frankel et al., 2008).

Another research by Zhu et al. (2008) showed that miR21 interacted with PDCD4's 3'UTR, resulting in its reduced expression in MDA-MB-231 cells. Anti-miR-21 also led to increased PDCD4 expression, indicating the role of miR-21 in breast cancer cell invasion by directly interacting with the PDCD4 target gene (Zhu et al., 2008).

\section{Tropomyosin-1 (TPM1)}

Tropomyosin-1, also known as TM1 and the actin-binding cytoskeletal protein, is a TPM family isoform that functions as a tumour suppressor gene by preventing cancer cell invasion by persuading apoptosis (Wang et al., 2015; Pan et al., 2017; Qi et al., 2009; Wang et al., 2019). Downregulation of TPM1 has been observed in breast cancer, glioma cancer, renal cell carcinoma, human oral squamous cell carcinoma (OSCC), and cholangiocarcinoma (Wang et al., 2015; Dube et al., 2015; Pan et al., 2017; Bharadwaj and Prasad, 2002; Yang et al., 2013; Ku et al., 2010). The expression of TPM1 in the OSCC is regulated by miR-21 (Pan et al., 2017). In addition, Zhu et al. (2007) in their report, showed that TPM1 is targeted by miR-21 in breast cancer to inhibit the TPM1 mediated apoptosis of cancer cells. They conducted twodimensional differentiation in-gel electrophoresis, where they found the upregulated TPM1 expression in tumors procured from MCF-7 cells by antisense miR-21 oligonucleotides (antimiR-21). miR-21 controls TPM1 expression by base-pairing with the V1 variant 3'UTR of TPM1, including miR-21's putative binding sites. For further evidence, the V1-3'UTR was cloned into a luciferase reporter. Luciferase assay results suggested that anti-miR-21 increased Luc-TPM1-V1-UTR activity, while miR-21 decreased its activity. Moreover, the effect of miR-21 inhibition on TPM1 was also tested at the level of translation. MTT assay revealed that TPM1-V1 repressed the growth of MCF-7 cells in vitro, and soft agar assay results also showed that TPM1-V1 reduced colony formation leading to anchorage-independent growth repression. Altogether, we can conclude that miR-21 uses TPM1 to control its expression in MCF-7 cells as a novel target.

\section{Phosphatase and tensin homolog (PTEN)}

PTEN on chromosome 10 is recognized as a tumor suppressor gene coding 403 amino acids protein, which functions as a metabolic regulator of a number of cellular processes like glycogen synthesis, lipid and mitochondrial metabolism, glycolysis, and gluconeogenesis (Chen et al., 2018). It has dephosphorylation activities for both proteins and lipids due to which it is known as dual phosphatase enzyme (Chu and Tarnawski, 2004). PTEN has five domains: 1) N-terminal domain, responsible for the binding of phosphatidylinositol phosphate (PIP) substrates; 2) Phosphatase domain, carries 


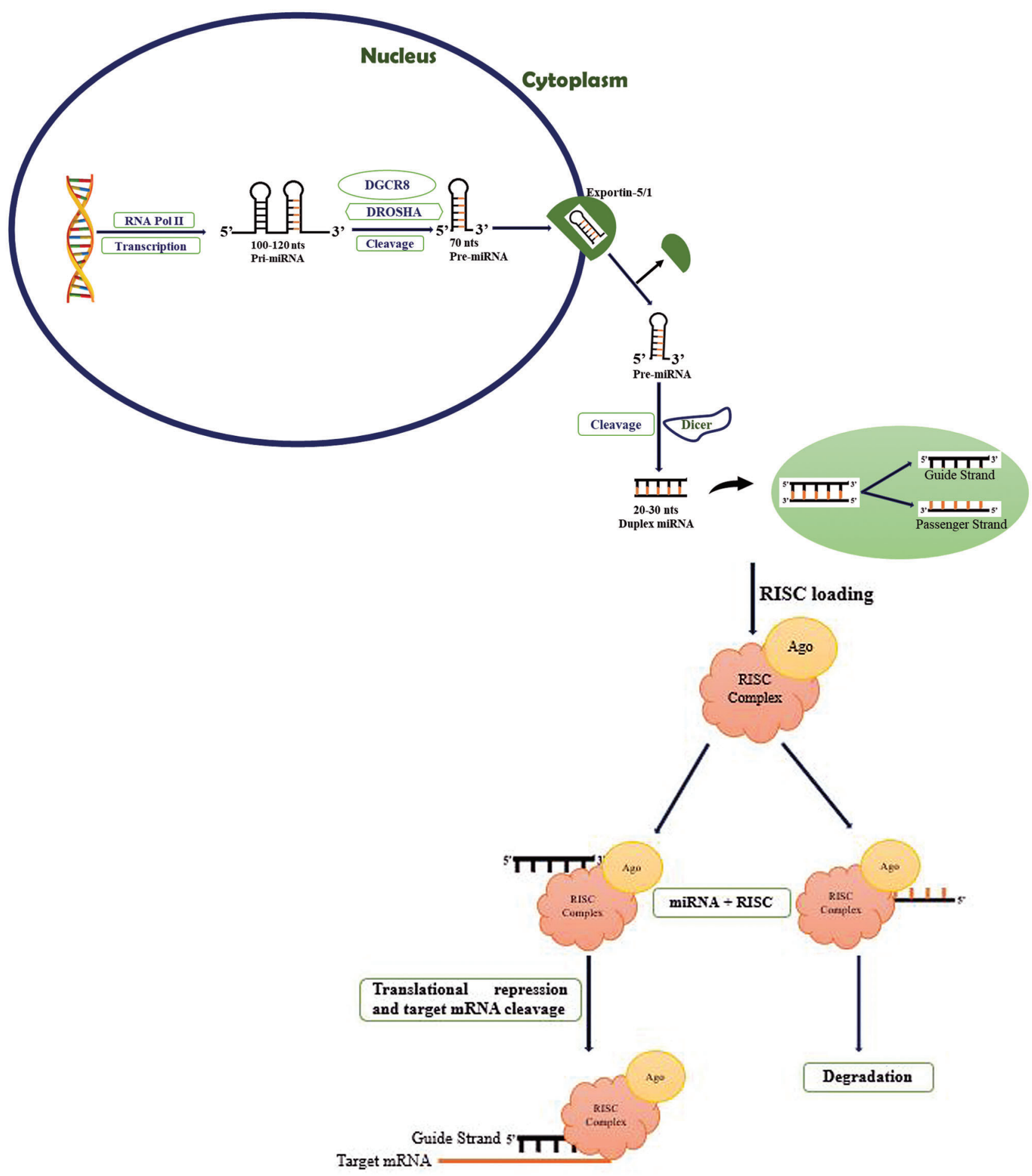

FIGURE 1. Biosynthesis of miRNA. RNA polymerase II is responsible for the transcription of 100-120 nts pri-miRNA in the nucleus. The primiRNA is trimmed into 70 nts pre-miRNA by DROSHA and DGCR8, which is then exported by exportin 5/1 into the cytoplasm, where it is further processed by Dicer enzyme forming 20-30 nts duplex miRNA with the guide (5' to 3') and passenger (3' to 5') strands. The guide strand interacts with the PAZ domain of the RISC, causing Argonaute 2 (AGO2) to cause post-transcriptional gene silencing and cleavage of the target mRNA, while the RISC's PIWI domain degrades the passenger strand.

acetylation sites and CX5R signature motif for the enzymatic actions; 3) C2 domain, a regulatory domain which contains a phospholipid-binding site and known for PTEN cell localization; 4) C-tail, which preserves phospho-sites and is responsible for the stability of protein; 5) PDZ domain, which is not well known (as shown in Fig. 4) (Chu and Tarnawski, 2004; Jerde, 2015; Chen et al., 2018). PTEN has regulatory functions in several processes, including cell migration, cell cycle arrest, MAP kinase signaling and angiogenesis (Chu and Tarnawski, 2004). Any mutations in PTEN gene lead to the progression of sporadic breast cancer, renal cell carcinoma, ovarian cancer, lung cancer, thyroid cancer, lymphoma cancer, hepatocellular carcinoma, lymphoma, head \& neck cancer, prostate cancer, and glioblastoma (Chu and Tarnawski, 2004; Meng et al., 2007; Halachmi et al., 1998; Shao et al., 1998; Forgacs et al., 1998; 


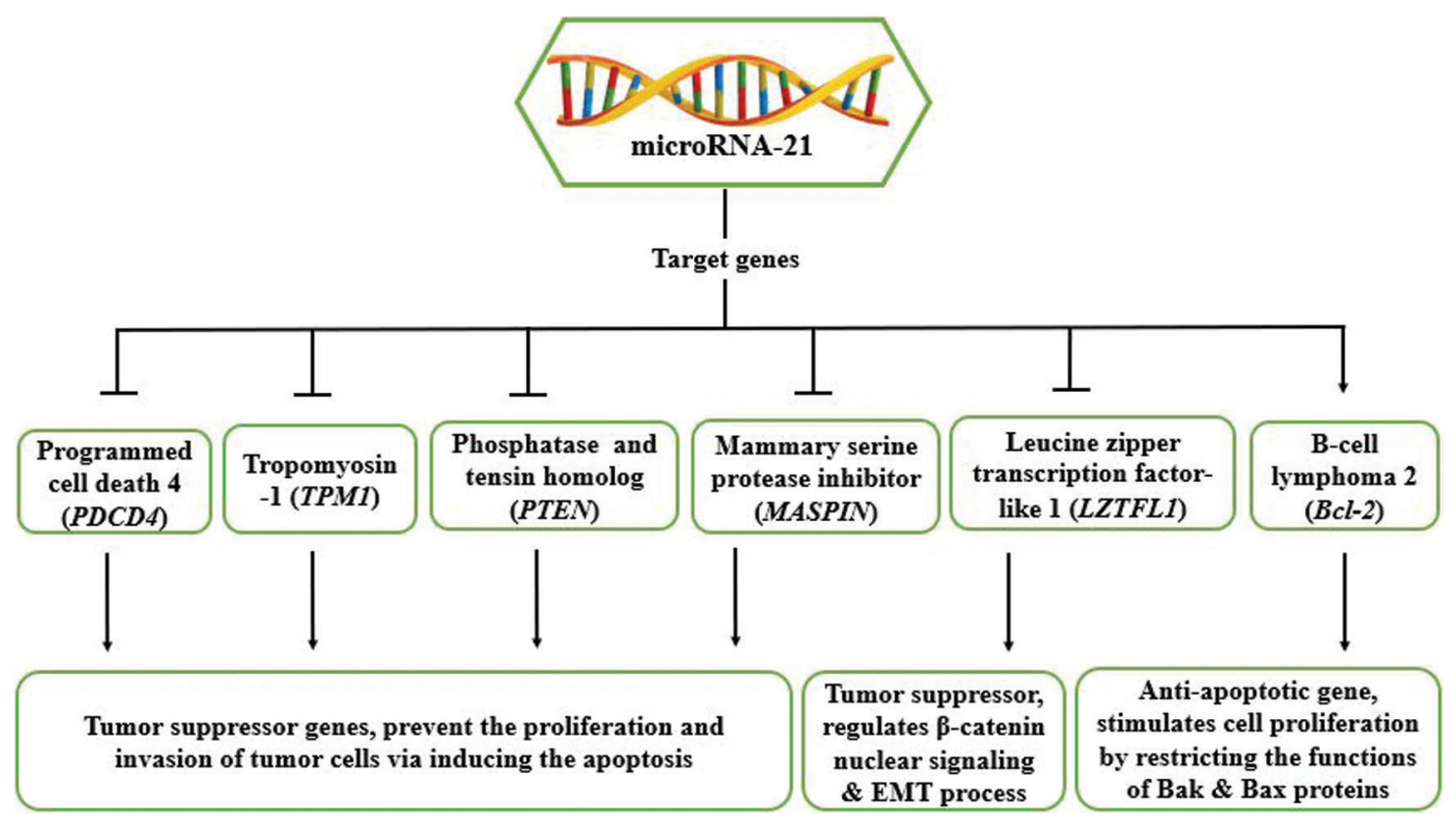

FIGURE 2. Depicts miR-21's target genes and their functions in tumorigenesis.

A

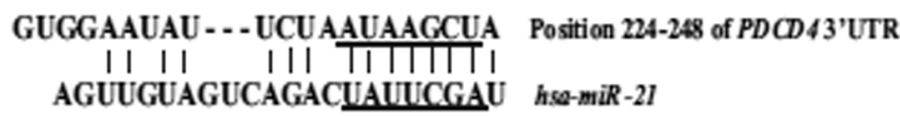

C

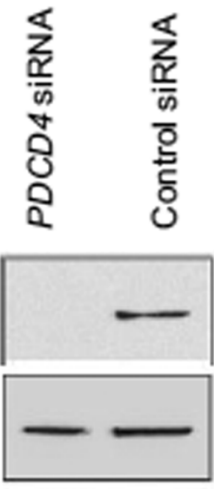

PDCD4

Vinculin
B

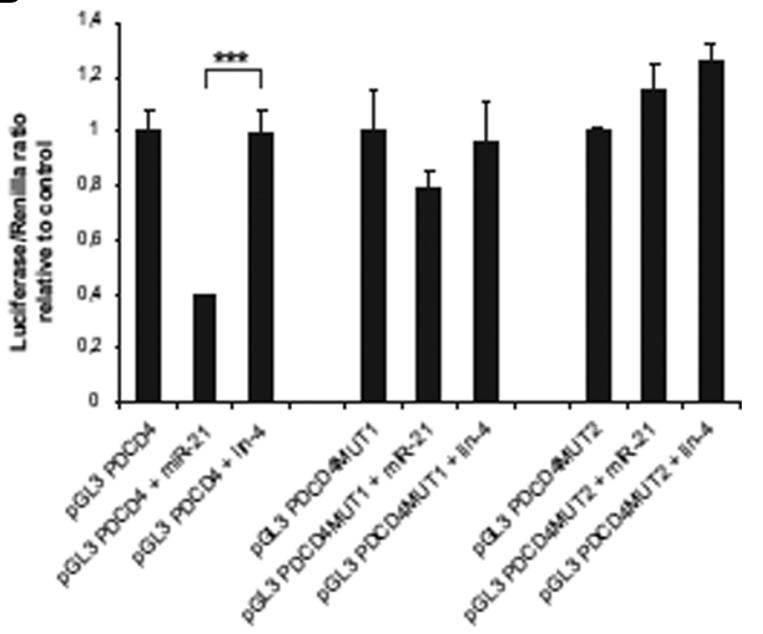

D

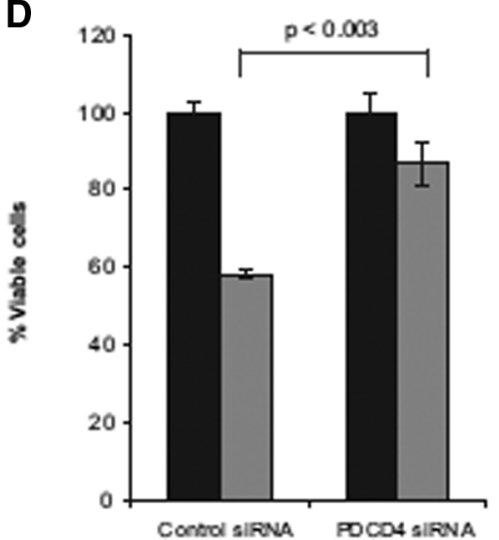

- LNAGcramble

口LNAM R-21

FIGURE 3. Represents that PDCD4 is a putative target of miR-21. A) shows the interaction of miR-21 with the 3 'UTR of PDCD4. B) shows firefly luciferase reporter assay results, where co-transfection of HEK cells was done with pGL3-PDCD4, pGL3-PDCD4MUT1, pGL3PDCD4MUT2 along with a Renilla luciferase transfection control plasmid, either alone or together with miR-21/lin-4 precursor miRNAs. Shown are relative luciferase values normalized to transfections without miRNA. Data are shown as the mean S.D. of four replicates and are representative of two independent experiments. ${ }^{* * *}$, p_0.001 using a two-tailed $t$ test. C) shows western blotting results where siRNA mediated knockdown of PDCD4 was shown in MCF-7 cells. D) shows the growth assay of PDCD4/control siRNA treated 3-(4,5dimethylthiazol-2-yl)-2,5-diphenyltetrazolium bromide in MCF-7 cells and transfection with inhibitors against miR-21/a scrambled control. Quantification of cell number was done after 5 days of transfection. Data are shown as the mean _ S.D. of three replicates and are representative of three independent experiments. The $p$ value was calculated using a two-tailed $t$ test (Frankel et al., 2008). 


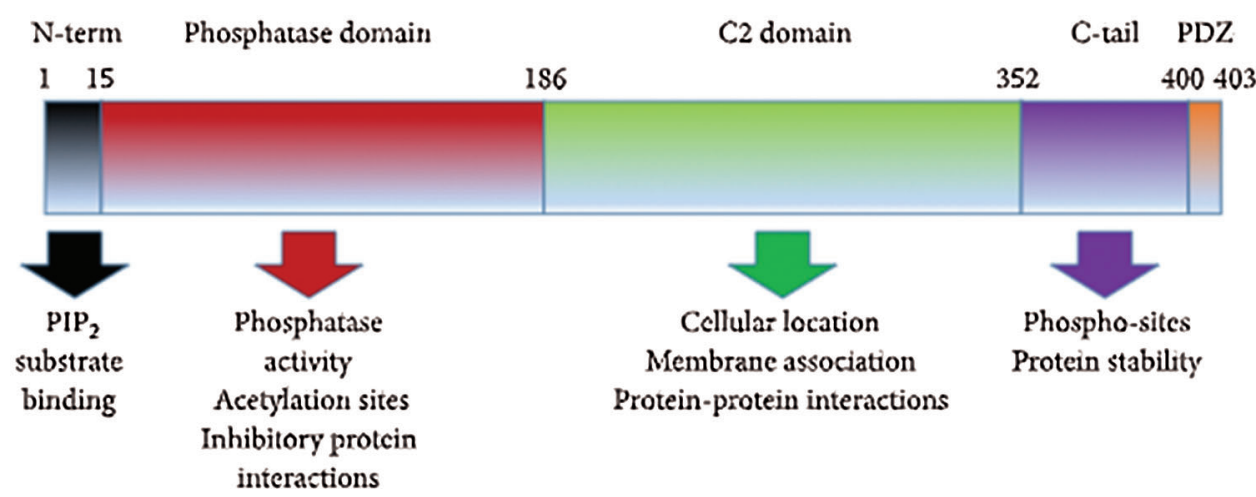

FIGURE 4. Protein domains of PTEN (Jerde, 2015).
Saito et al., 2000). In human hepatocellular cancer, miR-21 is known to regulate the PTEN expression and pathways which are mediated by PTEN (Meng et al., 2007).

A research conducted by Gong et al. (2014) showed that miR-21 decreases PTEN expression in tumors of breast phyllodes. Like PDCD4 and TPM1, PTEN also has miR-21 binding sequences at 3'UTR (Zhu et al., 2007; Frankel et al., 2008; Gong et al., 2014). PTEN protein levels were increased via miR-21 antisense oligonucleotides while, decreased via miR-21 mimics in stromal fibroblasts, demonstrating the role of miR-21 in targeting PTEN to increase the proliferation of phyllodes tumors cells (Gong et al., 2014). PTEN is known for the regulation of fibroblast activation protein (FAP) function (FAP is familiar as a serine protease and myofibroblast marker to increase the proliferation of phyllodes tumors) (Liu et al., 2012; Gong et al., 2014). The PTEN knockdown raised the protein expression levels of FAP during the myofibroblast differentiation process, suggesting the role of PTEN in proliferation. Moreover, reintroduction of PTEN resulted in a decrease in both PTEN mRNA and protein levels in benign tumors, thus inhibiting the proliferation of tumor cells by miR-21. Together, these findings concluded that miR-21 downregulates the PTEN expression to induce cell proliferation by increasing FAP expression in breast phyllodes tumor (Gong et al., 2014).

Mammary Serine Protease Inhibitor (MASPIN)

Mammary serine protease inhibitor is related to the serpin family (serine protease inhibitor family) (Zhang, 2002). Due to its ability to prevent tumor invasion by inducing apoptosis in tumor cells found on the 18q21.3-q23 chromosome, it is also recognized as a tumor suppressor gene (Berardi et al., 2013; Zhang, 2002). It is also known to prevent the process of angiogenesis (Zhang, 2002). Owing to its nuclear/cytoplasmic location in cancer cells, its expression is downregulated in various cancers like breast, gastric, prostate, melanoma and upregulated in gallbladder, thyroid, colorectal, pancreatic cancers (Berardi et al., 2013).

Maspin decreased MDA-MB-231 tumour cell invasion in the case of breast cancer (Zhu et al., 2008). With Flag-tagged maspin, they transfected MDA-MB-231 cells and confirmed the invasiveness of tumour cells through western blotting. However, by targeting it, the oncomir miR-21 downregulated maspin expression in MDA-MB-231 cells. Maspin also has 3'UTR binding sites for miR-21, so they cloned 3'UTR of maspin into pGL3 vector (luciferase gene) to check the Luc-Maspin-3'UTR luciferase activity. They found that miR-21 repression of luciferase activity was greater than $40 \%$. Furthermore, anti-miR-21 increased the maspin expression, leading to the conclusion that by targeting its 3'UTR, miR-21 inhibits the maspin expression in MDA-MB-231 cells (Zhu et al., 2008).

\section{B-cell Lymphoma 2 gene (Bcl-2)}

B-cell lymphoma 2 is a $26 \mathrm{kDa}$ protein present on human chromosome 18q21 with a hydrophobic carboxyl terminus positioned on the outer mitochondrial membrane and an anti-apoptotic gene as well ( $\mathrm{Lu}$ et al., 1996). It suppresses
A

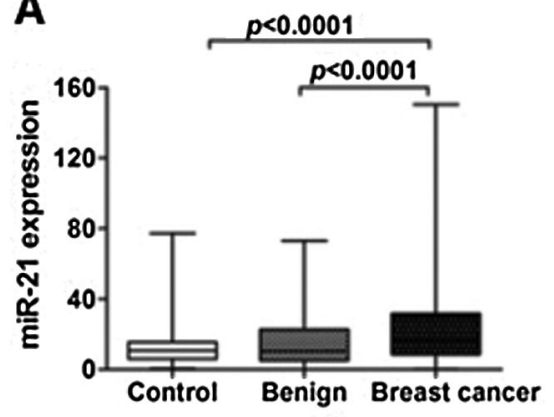

B

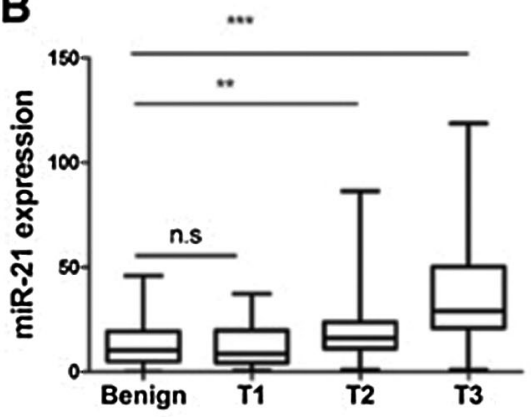

C

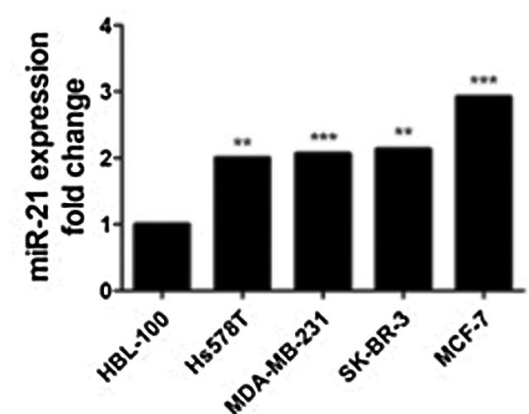

FIGURE 5. The levels of miR-21 in breast cancer patient plasma and cell lines. (A) Plasma miR-21 levels in 252 breast cancer patients, 127 healthy controls, and 82 benign breast cancer patients $(p<0.0001)$. (B) Plasma miR-21 levels in luminal A, luminal B, Her-2+ and basal-like types of breast cancer patients $(p<0.05)$. (C) The mRNA levels of miR-21 in HBL-100, Hs578T, MDA-MB-231, SK-BR3, and MCF-7 cell lines $\left({ }^{*} p<0.05,{ }^{* *} p<0.01,{ }^{* * *} \mathrm{p}<0.001\right)$ (Wang et al., 2019). 


\section{LZTFL1 3'-UTR 341-347 nt 5'...UUAAUAAAUGUUAAAUAAGCUAACAA....3'}

hsa-miR-21

\section{LZTFLI 3'-UTR mutant}

\section{3'...AGUUGUAGUCAGAC UAUUCGAU...5'}

\section{5'...UUAAUAAAUGUUAA GUAGCGCAACAA....'}

FIGURE 6. The predicted binding site of miR-21 in the 3'-UTR of wild type and mutant LZTFL1 (Wang et al., 2019). the caspase-mediated cell death and stimulates cell proliferation by restricting the function of pro-apoptotic proteins, Bak and Bax (Lu et al., 1996; Wickramasinghe et al., 2009). Upregulated levels of bcl-2 gene are found in many cancers like lymphoma, breast, colorectal, thyroid, and cervical (Flangea et al., 2008; Manne et al., 2000; Zhou and Wang, 2015). Research on human glioblastoma U87MG cells revealed that miR-21 overexpression resulted in decreased Bax expression and increased bcl-2 gene expression along with reduced caspase- 3 activity (Shi et al., 2010). Similarly, miR-21 controls tumorigenesis by upregulating the expression of the bcl-2 gene in breast cancer as miR-21 was highly overexpressed in breast tumors compared to the matched normal breast tissues 157 human miRNAs analysed. (Si et al., 2007). To investigate the function of miR-21, MCF-7 cells were transfected with anti-miR-21 oligonucleotide.

They showed that anti-miR-21 inhibits in vitro cell growth and tumor growth in the xenograft mouse model. Furthermore, to assess anti-miR-21 induced apoptosis, transfected cells were given $\mathrm{Z}-\mathrm{VAD}$-fmk, a caspase inhibitor, to counteract growth inhibition mediated by anti-miR-21. Apoptosis was caused by reduced Bcl-2 protein expression in anti-miR-21 transfected MCF-7 cells. These findings concluded that miR- 21 should be used as a therapeutic target for breast cancer because of its essential function in controlling the $\mathrm{Bcl}-2$ gene ( $\mathrm{Si}$ et al., 2007). In another study, breast cancer cell lines were developed, which are paclitaxel-resistant, and it was shown that down regulation of miR-21 via its mimic enhance the sensitivity against paclitaxel in the developed cell lines and increase the expression of Bcl-2 (Zhao et al., 2015).

\section{Leucine Zipper Transcription Factor-like 1 (LZTFL1)}

The $3 \mathrm{p} 21.3$ region of the chromosome contains the leucine zipper transcription factor-like 1 (LZTFL-1) gene expressed in epithelial cells of a diversity of normal cells (Wei et al., 2010). LZTFL-1, a cytoplasmic protein, regulates $\beta$-catenin nuclear signaling, ciliary protein trafficking, and the epithelial-mesenchymal transition (EMT) process (Wei et al., 2016). It represses EMT by inhibiting the mitogen-activated protein kinase (MAPK) signaling pathway, which is especially important in lung cancer (Wei et al., 2010; Wei et al., 2019). It functions as a tumor suppressor by stabilizing E-cadherin-mediated adherens junctions and inhibiting $\beta$-catenin relocation into the nucleus, preventing cell invasion and EMT-mediated breast cancer metastasis (Wang et al., 2014; Wang et al., 2019). Wang et al. (2019) discovered that LZTFL1 could be used as a new target in breast cancer cells via miR-21, facilitating cell invasion and metastasis. miR-21 was found to be upregulated in the plasma of three patient groups and various cell lines.

The level of plasma miR-21 was significantly higher in the breast cancer patient group than the benign breast cancer patient group and healthy control group (see Fig. 5A), suggesting that plasma miR-21 level may be used as a potential diagnostic biomarker for breast cancer. The histopathological examination showed an upregulated level of miR-21 in breast cancer types Her-2+ and luminal B (as shown in Fig. 5B), and in vitro analysis results showed miR-21 upregulate in all cell lines of breast cancer (MDA-MB-231, Hs578T, MCF-7, and SK-BR3) compared to immortalized mammary epithelial (HBL-100) cell line (see Fig. 5C). As demonstrated by luciferase reporter assay, miR-21 directly targets LZTFL1, where miR-21 overexpression resulted in decreased luciferase activity in HEK293T cells transfected with luciferase gene containing either wild-type or mutant 3'UTR of LZTFL1 (see Fig. 6).

The miR-21/LZTFL1/-catenin axis induces the EMT process. The effect of miR-21 inhibition and LZTFL1 knockdown on various EMT markers such as $\mathrm{N}$-cadherin, vimentin, E-cadherin and claudin-1. miR-21 inhibition decreased N-cadherin and vimentin expression while increasing E-cadherin and claudin-1 expression, whereas LZTFL1 knockdown reversed the expression of these markers (as shown in Fig. 7). Immunofluorescence assay

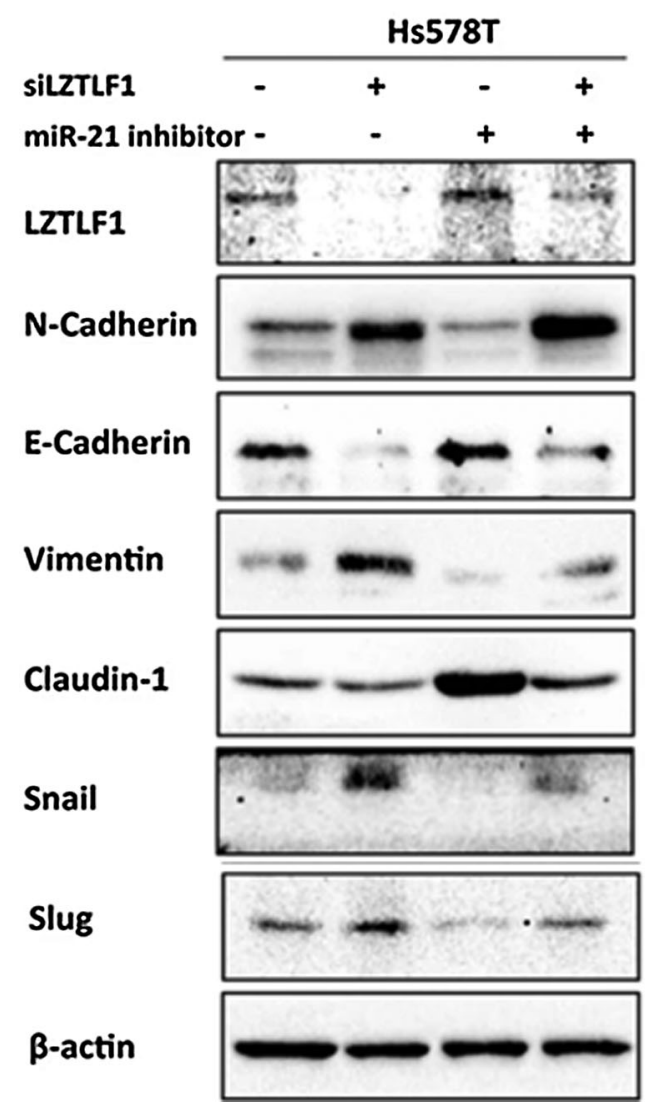

FIGURE 7. miR-21/LZTFL1 regulates $\beta$-catenin nuclear translocation and EMT process. The protein levels of EMT markers in Hs578T cells treated with miR-21 inhibitor, LZTFL1 siRNA alone, or combined for $48 \mathrm{~h}$ (Wang et al., 2019). 
revealed that translocation of $\beta$-catenin in the nucleus was increased by miR-21 which contributed to the transcription of snail and slug transcription factors (EMT markers) (as shown in Fig. 7), while LZTFL1 repressed it. Therefore, miR21 controls EMT by suppressing the LZTFL1, which increases $\beta$-catenin nuclear translocation, resulting in breast cancer proliferation and metastasis. This was also proved in $\mathrm{BALB} / \mathrm{c}$ nude mice inoculated with Hs578T (human breast cancer) cells. miR-21 overexpression increased tumor size, weight, and volume (see Figs. 8A-8C) as well as lymph node invasion (see Figs. 8D and 8E). Furthermore, overexpression of miR-21 increased metastasis in liver and lung tissues (as shown in Figs. 8F and 8G) (Wang et al., 2019).

\section{Summary}

There is an extensive role of 'oncomiR' miR-21 in various stages breast cancer viz invasion, development, and metastasis. Different studies have demonstrated miR-21 upregulation in breast cancer cells by targeting multiple genes involved in breast cancer tumorigenesis. As mentioned above, miR-21 overexpression, through the downregulation of tumour suppressor genes, increases cell proliferation (Frankel et al., 2008; Zhu et al., 2007; Gong et al., 2014). miR-21 specifically interacts with PDCD4, TPM1, PTEN, and maspin 3'UTR, contributing to the suppression of apoptotic activities (Frankel et al., 2008; Zhu et al., 2007; Zhu et al., 2008; Gong et al., 2014). It also promotes breast cancer cell proliferation by increasing the bcl-2 gene expression. These studies indicate that alteration in the expression of miR-21 can be a beneficial intervention in the treatment of breast cancer. Various molecular biology-based techniques have been developed to detect the alteration in the expression of miR-21. Besides this, biosensor-based detection of miR-21 is a new area of research that could be more accessible and can help in point-of-care testing (Wang et al., 2020; Meng et al., 2020; Sun et al., 2018). Another sensitive tool to detect miR-21 in breast cancer is DNAPeptide dendrimer and mass spectrometric method. It would also be essential to understand the role of miRNA in connection with the changing microbiome, which will help in early diagnosis and be used as a therapeutic biomarker (Allegra et al., 2020; Rastogi et al., 2020; Kashyap et al., 2021).
A

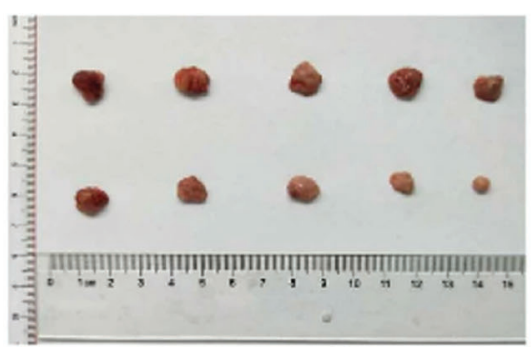

D

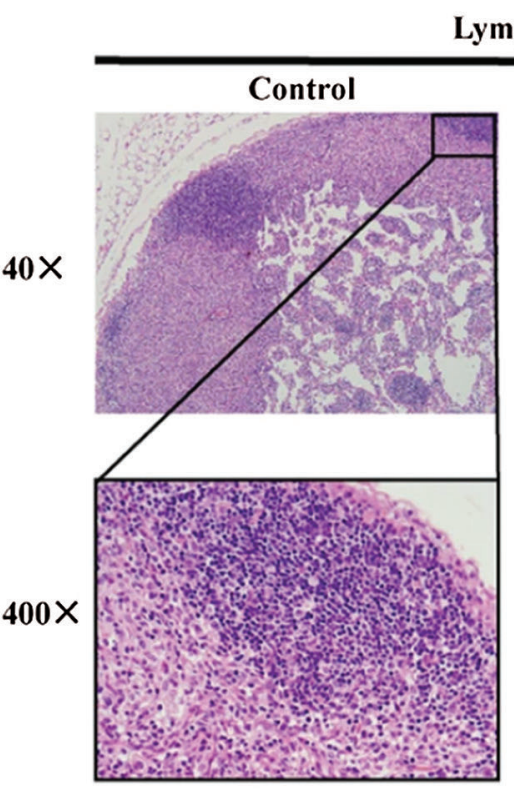

B

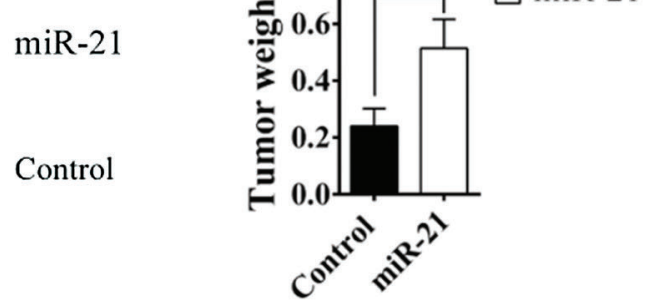

C

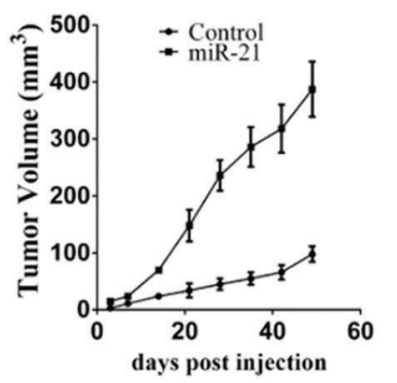

E

Lymph node

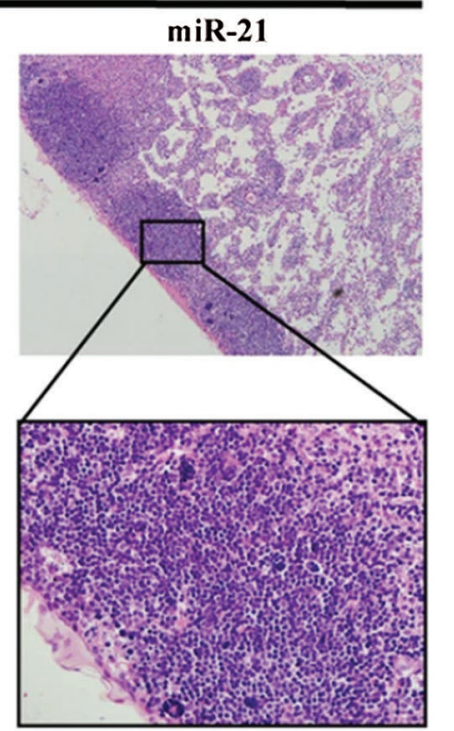

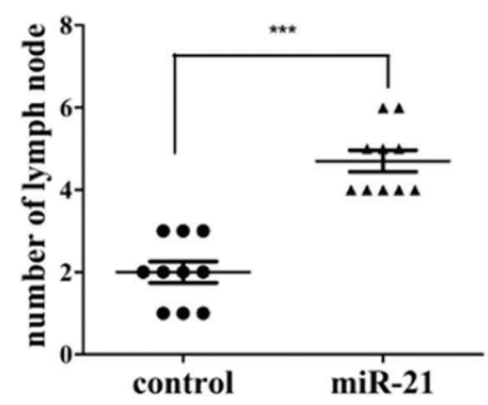

$\mathbf{F}$

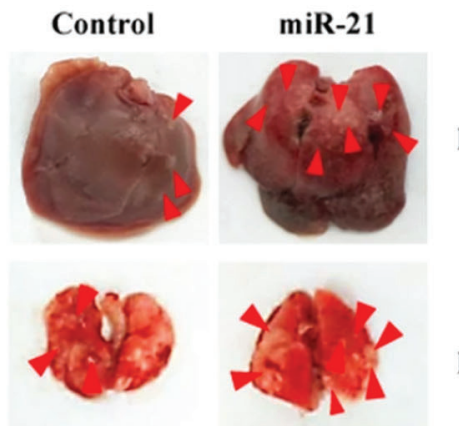

Liver

ung

FIGURE 8. miR-21 promotes breast cancer proliferation and metastasis in vivo. (A) Xenografted tumors were obtained from miR-21-treated Hs578T and control Hs578T cells in situ. (B and C) Tumor weight and volume were observed and recorded in the groups indicated above. ( $\mathrm{D}$ and $\mathrm{E}$ ) The number of lymph nodes invaded was determined. (F and G) Liver and lung tissues were obtained, and the metastatic cells were visualized (Wang et al., 2019). 
Acknowledgement: Authors acknowledge the support from Maharishi Markandeshwar (Deemed to be University) Mullana and Shoolini University, Solan.

Author Contribution: The authors confirm contribution to the paper as follows: study conception and design: AKS, RVS; data collection: PT, NKS, AC; draft manuscript preparation: PT, VKT, SSS. All authors compared different studies and approved the final version of the manuscript.

Funding Statement: Authors received no specific funding for this study.

Conflicts of Interest: The authors declare that they have no conflicts of interest to report regarding the present study.

\section{References}

Abdel-hamid NR, Mohammed EA, Abbas AH, Badr FM (2015). MicroRNA-21 expression in primary breast cancer tissue among Egyptian female patients and its correlation with chromosome 17 aneusomy. Molecular Diagnosis \& Therapy 19: $365-373$.

Adams BD, Furneaux H, White BA (2007). The micro-ribonucleic acid (miRNA) miR-206 targets the human estrogen receptor- $\alpha(E R \alpha)$ and represses $E R \alpha$ messenger RNA and protein expression in breast cancer cell lines. Molecular Endocrinology 21: 1132-1147.

Adhami M, Haghdoost AA, Sadeghi B, Afshar RM (2018). Candidate miRNAs in human breast cancer biomarkers: A systematic review. Breast Cancer 25: 198-205.

Alarcón CR, Goodarzi H, Lee H, Liu X, Tavazoie S, Tavazoie SF (2015a). HNRNPA2B1 is a mediator of m6A-dependent nuclear RNA processing events. Cell 162: 1299-1308.

Alarcón CR, Lee H, Goodarzi H, Halberg N, Tavazoie SF (2015b). N 6-methyladenosine marks primary microRNAs for processing. Nature 519: 482-485.

Allegra A, Musolino C, Tonacci A, Pioggia G, Gangemi S (2020). Interactions between the MicroRNAs and microbiota in cancer development: Roles and therapeutic opportunities. Cancers (Basel) 4: 805.

Ataollahi MR, Sharifi J, Paknahad MR, Paknahad A (2015). Breast cancer and associated factors: A review. Journal of Medicine and Life 8: 6 .

Balcells I, Cirera S, Busk PK (2011). Specific and sensitive quantitative RT-PCR of miRNAs with DNA primers. BMC Biotechnology 11: 1.

Bandini E, Fanini F, Vannini I, Rossi T, Plousiou M et al. (2020). miR-9-5p as a regulator of the androgen receptor pathway in breast cancer cell lines. Frontiers in Cell and Developmental Biology 8: 579160.

Barbano R, Pasculli B, Rendina M, Fontana A, Fusilli C et al. (2017). Stepwise analysis of MIR9 loci identifies miR-9-5p to be involved in Oestrogen regulated pathways in breast cancer patients. Scientific Reports 7: 1-2.

Bayraktar R, Ivan C, Bayraktar E, Kanlikilicer P, Kabil NN et al. (2018). Dual suppressive effect of miR-34a on the FOXM1/ eEF2-kinase axis regulates triple-negative breast cancer growth and invasion. Clinical Cancer Research 24: 42254241.

Becker S (2015). A historic and scientific review of breast cancer: The next global healthcare challenge. International Journal of Gynecology \& Obstetrics 131: S36-S39.
Behm-Ansmant I, Rehwinkel J, Doerks T, Stark A, Bork P, Izaurralde E (2006). mRNA degradation by miRNAs and GW182 requires both CCR4: NOT deadenylase and DCP1: DCP2 decapping complexes. Genes \& Development 20: 1885-1898.

Berardi R, Morgese F, Onofri A, Mazzanti P, Pistelli M et al. (2013). Role of maspin in cancer. Clinical and Translational Medicine 2: 1-9.

Bharadwaj S, Prasad GL (2002). Tropomyosin-1, a novel suppressor of cellular transformation is downregulated by promoter methylation in cancer cells. Cancer Letters 183: 205-213.

Brown CY, Dayan S, Wong SW, Kaczmarek A, Hope CM et al. (2018). FOXP3 and miR-155 cooperate to control the invasive potential of human breast cancer cells by down regulating ZEB2 independently of ZEB1. Oncotarget 9: 27708-27727.

Calin GA, Sevignani C, Dumitru CD, Hyslop T, Noch E et al. (2004). Human microRNA genes are frequently located at fragile sites and genomic regions involved in cancers. Proceedings of the National Academy of Sciences of the United States of America 101: 2999-3004.

Casalini P, Iorio MV (2009). MicroRNAs and future therapeutic applications in cancer. Journal of Buon 14: S17-S22.

Chandrasekaran AR, MacIsaac M, Dey P, Levchenko O, Zhou L, Andres M, Dey BK, Halvorsen K (2019). Cellular microRNA detection with miRacles: microRNA-activated conditional looping of engineered switches. Science Advances 5: eaau9443.

Chen CY, Chen J, He L, Stiles BL (2018). PTEN: Tumor suppressor and metabolic regulator. Frontiers in Endocrinology 9: 338.

Chen D, Sun Y, Wei Y, Zhang P, Rezaeian AH et al. (2012). LIFR is a breast cancer metastasis suppressor upstream of the HippoYAP pathway and a prognostic marker. Nature Medicine 18: 1511-1517.

Chen Z, Pan T, Jiang D, Jin L, Geng Y, Feng X, Shen A, Zhang L (2020). The IncRNA-GAS5/miR-221-3p/DKK2 axis modulates ABCB1-mediated adriamycin resistance of breast cancer via the Wnt/ $\beta$-catenin signaling pathway. Molecular Therapy-Nucleic Acids 19: 1434-1448.

Cheng CW, Wang HW, Chang CW, Chu HW, Chen CY et al. (2012). MicroRNA-30a inhibits cell migration and invasion by downregulating vimentin expression and is a potential prognostic marker in breast cancer. Breast Cancer Research and Treatment 134: 1081-1093.

Christoffersen NR, Shalgi R, Frankel LB, Leucci E, Lees M et al. (2010). p53-independent upregulation of miR-34a during oncogene-induced senescence represses MYC. Cell Death \& Differentiation 17: 236-245.

Chu EC, Tarnawski AS (2004). PTEN regulatory functions in tumor suppression and cell biology. Medical Science Monitor 10: RA235-RA241.

Cissell KA, Deo SK (2009). Trends in microRNA detection. Analytical and Bioanalytical Chemistry 394: 1109-1116.

Cochrane DR, Howe EN, Spoelstra NS, Richer JK (2010). Loss of miR200c: A marker of aggressiveness and chemoresistance in female reproductive cancers. Journal of Oncology 2010: 821717.

Creighton CJ, Reid JG, Gunaratne PH (2009). Expression profiling of microRNAs by deep sequencing. Briefings in Bioinformatics 10: 490-497.

Croce CM (2009). Causes and consequences of microRNA dysregulation in cancer. Nature Reviews Genetics 10: 704-714.

Denli AM, Tops BB, Plasterk RH, Ketting RF, Hannon GJ (2004). Processing of primary microRNAs by the Microprocessor complex. Nature 432: 231-235. 
Du Y, Lin Y, Yin K, Zhou L, Jiang Y, Yin W, Lu J (2019). Single nucleotide polymorphisms of let-7-related genes increase susceptibility to breast cancer. American Journal of Translational Research 11: 1748.

Dube S, Yalamanchili S, Lachant J, Abbott L, Benz P et al. (2015). Expression of tropomyosin 1 gene isoforms in human breast cancer cell lines. International Journal of Breast Cancer 2015: 859427.

Dykxhoorn DM, Wu Y, Xie H, Yu F, Lal A et al. (2009). miR-200 enhances mouse breast cancer cell colonization to form distant metastases. PLoS One 4: e7181.

Eichelser C, Stückrath I, Müller V, Milde-Langosch K, Wikman H, Pantel K, Schwarzenbach H (2014). Increased serum levels of circulating exosomal microRNA-373 in receptor-negative breast cancer patients. Oncotarget 5: 9650.

Eroles P, Bosch A, Pérez-Fidalgo JA, Lluch A (2012). Molecular biology in breast cancer: Intrinsic subtypes and signaling pathways. Cancer Treatment Reviews 38: 698-707.

Eulalio A, Huntzinger E, Izaurralde E (2008). GW182 interaction with Argonaute is essential for miRNA-mediated translational repression and mRNA decay. Nature Structural \& Molecular Biology 15: 346.

Fabian MR, Sonenberg N (2012). The mechanics of miRNAmediated gene silencing: A look under the hood of miRISC. Nature Structural \& Molecular Biology 19: 586.

Fang T, Jiang YX, Chen L, Huang L, Tian XH, Zhou YD, Nagle DG, Zhang DD (2020). Coix seed oil exerts an anti-triple-negative breast cancer effect by disrupting miR-205/S1PR1 axis. Frontiers in Pharmacology 11: 1518.

Feng YH, Tsao CJ (2016). Emerging role of microRNA-21 in cancer. Biomedical Reports 5: 395-402.

Filippov V, Solovyev V, Filippova M, Gill SS (2000). A novel type of RNase III family proteins in eukaryotes. Gene 245: 213-221.

Flangea C, Potencz E, Mihăescu R, Gîju S, Anghel A (2008). Bcl-2 expression in Hodgkin's lymphoma progression. Romanian Journal of Morphology Embryology 49: 357-363.

Forgacs E, Biesterveld EJ, Sekido Y, Fong K, Muneer S et al. (1998). Mutation analysis of the PTEN/MMAC1 gene in lung cancer. Oncogene 17: 1557-1565.

Frankel LB, Christoffersen NR, Jacobsen A, Lindow M, Krogh A, Lund AH (2008). Programmed cell death 4 (PDCD4) is an important functional target of the microRNA miR-21 in breast cancer cells. Journal of Biological Chemistry 283: 1026-1033.

Gao Y, Zhang W, Liu C, Li G (2019). miR-200 affects tamoxifen resistance in breast cancer cells through regulation of MYB. Scientific Reports 9: 1-6.

Garofalo M, Quintavalle C, Romano G, croce MC, Condorelli G (2012). miR221/222 in cancer: Their role in tumor progression and response to therapy. Current Molecular Medicine 12: 27-33.

Gong C, Nie Y, Qu S, Liao JY, Cui X, Yao H, Zeng Y, Su F, Song E, Liu $Q$ (2014). miR-21 induces myofibroblast differentiation and promotes the malignant progression of breast phyllodes tumors. Cancer Research 74: 4341-4352.

Gregory PA, Bert AG, Paterson EL, Barry SC, Tsykin A et al. (2008). The miR-200 family and miR-205 regulate epithelial to mesenchymal transition by targeting ZEB1 and SIP1. Nature Cell Biology 10: 593-601.

Gregory RI, Yan KP, Amuthan G, Chendrimada T, Doratotaj B, Cooch N, Shiekhattar R (2004). The Microprocessor complex mediates the genesis of microRNAs. Nature 432: 235-240.
Guo D, Guo J, Li X, Guan F (2018). Enhanced motility and proliferation by $\mathrm{miR}-10 \mathrm{~b} / \mathrm{FUT} 8 / \mathrm{p}-\mathrm{AKT}$ axis in breast cancer cells. Oncology Letters 16: 2097-2104.

Halachmi N, Halachmi S, Evron E, Cairns P, Okami K et al. (1998). Somatic mutations of the PTEN tumor suppressor gene in sporadic follicular thyroid tumors. Genes, Chromosomes and Cancer 23: 239-243.

Han M, Liu M, Wang Y, Chen X, Xu J et al. (2012a). Antagonism of miR-21 reverses epithelial-mesenchymal transition and cancer stem cell phenotype through AKT/ERK1/2 inactivation by targeting PTEN. PLoS One 7: e39520.

Han M, Liu M, Wang Y, Mo Z, Bi X, Liu Z, Fan Y, Chen X, Wu C (2012b). Re-expression of miR-21 contributes to migration and invasion by inducing epithelial-mesenchymal transition consistent with cancer stem cell characteristics in MCF-7 cells. Molecular and Cellular Biochemistry 363: 427-436.

Han M, Wang F, Gu Y, Pei X, Guo G et al. (2016). MicroRNA-21 induces breast cancer cell invasion and migration by suppressing smad7 via EGF and TGF- $\beta$ pathways. Oncology Reports 35: 73-80.

Hassan O, Ahmad A, Sethi S, Sarkar FH (2012). Recent updates on the role of microRNAs in prostate cancer. Journal of Hematology \& Oncology 5.

He L, Thomson JM, Hemann MT, Hernando-Monge E, Mu D et al. (2005). A microRNA polycistron as a potential human oncogene. Nature 435: 828-833.

Hemmatzadeh M, Mohammadi H, Jadidi-Niaragh F, Asghari F, Yousefi $M$ (2016). The role of oncomirs in the pathogenesis and treatment of breast cancer. Biomedicine \& Pharmacotherapy 78: 129-139.

Hesari Z, Nourbakhsh M, Hosseinkhani S, Abdolvahabi Z, Alipour M et al. (2018). Down-regulation of NAMPT expression by mir206 reduces cell survival of breast cancer cells. Gene 673: 149-158.

Höck J, Meister G (2008). The Argonaute protein family. Genome Biology 9: 1-8.

Hong T, Ding J, Li W (2019). Mir-7 reverses breast cancer resistance to chemotherapy by targeting MRP1 and BCL2. Onco Targets and Therapy 12: 11097.

Hossain A, Kuo MT, Saunders GF (2006). Mir-17-5p regulates breast cancer cell proliferation by inhibiting translation of AIB1 mRNA. Molecular and Cellular Biology 26: 8191-8201.

Huang Q, Gumireddy K, Schrier M, Le Sage C, Nagel R et al. (2008). The microRNAs miR-373 and miR-520c promote tumour invasion and metastasis. Nature Cell Biology 10: 202-210.

Imani S, Zhang X, Hosseinifard H, Fu S, Fu J (2017). The diagnostic role of microRNA-34a in breast cancer: A systematic review and meta-analysis. Oncotarget 8: 23177.

Iorio MV, Casalini P, Piovan C, Di Leva G, Merlo A et al. (2009). microRNA-205 regulates HER3 in human breast cancer. Cancer Research 69: 2195-2200.

Iorio MV, Ferracin M, Liu CG, Veronese A, Spizzo R et al. (2005). MicroRNA gene expression deregulation in human breast cancer. Cancer Research 65: 7065-7070.

Jerde TJ (2015). Phosphatase and tensin homologue: Novel regulation by developmental signaling. Journal of Signal Transduction 2015: 282567.

Jiang CF, Shi ZM, Li DM, Qian YC, Ren Y et al. (2018). Estrogeninduced miR-196a elevation promotes tumor growth and metastasis via targeting SPRED1 in breast cancer. Molecular Cancer 17: 1-8.

Jiang M, Zhang W, Zhang R, Liu P, Ye Y et al. (2020). Cancer exosome-derived miR-9 and miR-181a promote the 
development of early-stage MDSCs via interfering with SOCS3 and PIAS3 respectively in breast cancer. Oncogene 39: 4681-4694.

Jiang Y, Jia Y, Zhang L (2017). Role of programmed cell death 4 in diseases: A double-edged sword. Cellular \& Molecular Immunology 14: 884-886.

Johnson SM, Grosshans H, Shingara J, Byrom M, Jarvis R et al. (2005). RAS is regulated by the let-7 microRNA family. Cell 120: 635-647.

Kashyap S, Pal S, Chandan G, Saini V, Chakrabarti S et al. (2021). Understanding the cross-talk between human microbiota and gastrointestinal cancer for developing potential diagnostic and prognostic biomarkers. Seminars in Cancer Biology, S1044-S579X(21)00121-8. DOI 10.1016/j. semcancer.2021.04.020.Epub ahead of print.

Kawaguchi T, Yan L, Qi Q, Peng X, Gabriel EM et al. (2017). Overexpression of suppressive microRNAs, miR-30a and miR-200c are associated with improved survival of breast cancer patients. Scientific Reports 7: 1-2.

Keklikoglou I, Koerner C, Schmidt C, Zhang JD, Heckmann D et al. (2012). MicroRNA-520/373 family functions as a tumor suppressor in estrogen receptor negative breast cancer by targeting NF- $\kappa \mathrm{B}$ and TGF- $\beta$ signaling pathways. Oncogene 31: $4150-4163$.

Khan S, Greco D, Michailidou K, Milne RL, Muranen TA et al. (2014). MicroRNA related polymorphisms and breast cancer risk. PLoS One 9: e109973.

Kia V, Paryan M, Mortazavi Y, Biglari A, Mohammadi-Yeganeh S (2019). Evaluation of exosomal miR-9 and miR-155 targeting PTEN and DUSP14 in highly metastatic breast cancer and their effect on low metastatic cells. Journal of Cellular Biochemistry 120: 5666-5676.

Kim EJ, Kim JS, Lee S, Lee H, Yoon JS et al. (2019). QKI, a miR-200 target gene, suppresses epithelial-to-mesenchymal transition and tumor growth. International Journal of Cancer 145: 1585-1595.

Kim J, Siverly AN, Chen D, Wang M, Yuan Y et al. (2016). Ablation of miR-10b suppresses oncogene-induced mammary tumorigenesis and metastasis and reactivates tumorsuppressive pathways. Cancer Research 76: 6424-6435.

Kim J, Yao F, Xiao Z, Sun Y, Ma L (2018). MicroRNAs and metastasis: Small RNAs play big roles. Cancer and Metastasis Reviews 37: 5-15.

Kim S, Lee E, Jung J, Lee JW, Kim HJ et al. (2018). microRNA-155 positively regulates glucose metabolism via PIK3R1-FOXO3acMYC axis in breast cancer. Oncogene 37: 2982-2991.

Kim VN (2005). MicroRNA biogenesis: Coordinated cropping and dicing. Nature Reviews Molecular Cell Biology 6: 376-385.

Klinge CM (2018). Non-coding RNAs in breast cancer: Intracellular and intercellular communication. Non-Coding RNA 4: 40.

Kobayashi H, Tomari Y (2016). RISC assembly: Coordination between small RNAs and Argonaute proteins. Biochimica et Biophysica Acta (BBA)-Gene Regulatory Mechanisms 1859: 71-81.

Kong W, Yang H, He L, Zhao JJ, Coppola D et al. (2008). MicroRNA155 is regulated by the transforming growth factor $\beta / S$ mad pathway and contributes to epithelial cell plasticity by targeting RhoA. Molecular and Cellular Biology 28: 6773-6784.

Kong YW, Ferland-McCollough D, Jackson TJ, Bushell M (2012). microRNAs in cancer management. Lancet Oncology 13: e249-e258.

Kroczynska B, Sharma B, Eklund EA, Fish EN, Platanias LC (2012). Regulatory effects of programmed cell death 4 (PDCD4) protein in interferon (IFN)-stimulated gene expression and generation of type I IFN responses. Molecular and Cellular Biology 32: 2809-2822.

$\mathrm{Ku}$ BM, Ryu HW, Lee YK, Ryu J, Jeong JY et al. (2010). 4'-Acetoamido-4-hydroxychalcone, a chalcone derivative, inhibits glioma growth and invasion through regulation of the tropomyosin 1 gene. Biochemical and Biophysical Research Communications 402: 525-530.

Lee JA, Lee HY, Lee ES, Kim I, Bae JW (2011). Prognostic implications of microRNA-21 overexpression in invasive ductal carcinomas of the breast. Journal of Breast Cancer 14: 269-275.

Lee Y, Kim M, Han J, Yeom KH, Lee S et al. (2004). MicroRNA genes are transcribed by RNA polymerase II. EMBO Journal 23: 4051-4060.

Li B, Lu Y, Yu L, Han X, Wang H et al. (2017). miR-221/222 promote cancer stem-like cell properties and tumor growth of breast cancer via targeting PTEN and sustained Akt/NF- $\mathrm{kB} / \mathrm{COX}-2$ activation. Chemico-Biological Interactions 277: 33-42.

Li L, Yuan L, Luo J, Gao J, Guo J, Xie X (2013). MiR-34a inhibits proliferation and migration of breast cancer through downregulation of Bcl-2 and SIRT1. Clinical and Experimental Medicine 13: 109-117.

Li M, Pan M, Wang J, You C, Zhao F et al. (2020). MiR-7 reduces breast cancer stem cell metastasis via inhibiting RELA to decrease ESAM expression. Molecular Therapy-Oncolytics 18: $70-82$.

Li S, Yang X, Yang J, Zhen J, Zhang D (2016). Serum microRNA-21 as a potential diagnostic biomarker for breast cancer: a systematic review and meta-analysis. Clinical and Experimental Medicine 16: 29-35.

Li W, Ruan K (2009). MicroRNA detection by microarray. Analytical and Bioanalytical Chemistry 394: 1117-1124.

Li X, Zeng Z, Wang J, Wu Y, Chen W et al. (2020). MicroRNA-9 and breast cancer. Biomedicine \& Pharmacotherapy 122: 109687.

Li Y, Wang Y, Fan H, Zhang Z, Li N (2018). miR-125b-5p inhibits breast cancer cell proliferation, migration and invasion by targeting KIAA1522. Biochemical and Biophysical Research Communications 504: 277-282.

Li ZH, Weng X, Xiong QY, Tu JH, Xiao A et al. (2017). miR-34a expression in human breast cancer is associated with drug resistance. Oncotarget 8: 106270.

Liang YK, Lin HY, Dou XW, Chen M, Wei XL et al. (2018). MiR-221/ 222 promote epithelial-mesenchymal transition by targeting Notch3 in breast cancer cell lines. NPJ Breast Cancer 4: 1-9.

Liao XH, Xiang Y, Yu CX, Li JP, Li H et al. (2017). STAT3 is required for MiR-17-5p-mediated sensitization to chemotherapyinduced apoptosis in breast cancer cells. Oncotarget 8: 15763.

Lin X, Chen W, Wei F, Zhou BP, Hung MC et al. (2017). Nanoparticle delivery of miR-34a eradicates long-termcultured breast cancer stem cells via targeting C22ORF28 directly. Theranostics 7: 4805.

Liu DZ, Chang B, Li XD, Zhang QH, Zou YH (2017). MicroRNA-9 promotes the proliferation, migration, and invasion of breast cancer cells via down-regulating FOXO1. Clinical and Translational Oncology 19: 1133-1140.

Liu R, Li H, Liu L, Yu J, Ren X (2012). Fibroblast activation protein: A potential therapeutic target in cancer. Cancer Biology \& Therapy 13: 123-129.

Liu S, Wang Z, Liu Z, Shi S, Zhang Z et al. (2018). miR-221/ 222 activate the $\mathrm{Wnt} / \beta$-catenin signaling to promote 
triple-negative breast cancer. Journal of Molecular Cell Biology 10: 302-315.

Lo PK, Wolfson B, Zhou X, Duru N, Gernapudi R et al. (2016). Noncoding RNAs in breast cancer. Briefings in Functional Genomics 15: 200-221.

$\mathrm{Lu}$ QL, Abel P, Foster CS, Lalani EN (1996). bcl-2: Role in epithelial differentiation and oncogenesis. Human Pathology 27: 102-110.

Luthra R, Singh RR, Luthra MG, Li YX, Hannah C et al. (2008). MicroRNA-196a targets annexin A1: A microRNAmediated mechanism of annexin A1 downregulation in cancers. Oncogene 27: 6667-6678.

Lv C, Li F, Li X, Tian Y, Zhang Y et al. (2017). MiR-31 promotes mammary stem cell expansion and breast tumorigenesis by suppressing Wnt signaling antagonists. Nature Communications 8: 1-8.

M'hamed IF, Privat M, Trimeche M, Penault-Llorca F, Bignon YJ et al. (2017). miR-10b, miR-26a, miR-146a And miR-153 expression in triple negative $v s$. non triple negative breast cancer: Potential biomarkers. Pathology \& Oncology Research 23: 815-827.

Ma L, Reinhardt F, Pan E, Soutschek J, Bhat B et al. (2010). Therapeutic silencing of miR-10b inhibits metastasis in a mouse mammary tumor model. Nature Biotechnology 28: 341-347.

Ma L, Teruya-Feldstein J, Weinberg RA (2007). Tumour invasion and metastasis initiated by microRNA-10b in breast cancer. Nature 449: 682-688.

Ma L, Young J, Prabhala H, Pan E, Mestdagh P et al. (2010). miR-9, a MYC/MYCN-activated microRNA, regulates E-cadherin and cancer metastasis. Nature Cell Biology 12: 247-256.

MacFarlane LA, R Murphy P (2010). MicroRNA: Biogenesis, function and role in cancer. Current Genomics 11: 537-561.

Manne U, Weiss HL, Grizzle WE (2000). Bcl-2 expression is associated with improved prognosis in patients with distal colorectal adenocarcinomas. International Journal of Cancer 89: 423-430.

Mattie MD, Benz CC, Bowers J, Sensinger K, Wong L et al. (2006). Optimized high-throughput microRNA expression profiling provides novel biomarker assessment of clinical prostate and breast cancer biopsies. Molecular Cancer 5: 24 .

Mayr C, Hemann MT, Bartel DP (2007). Disrupting the pairing between let-7 and Hmga2 enhances oncogenic transformation. Science 315: 1576-1579.

Meerson A, Eliraz Y, Yehuda H, Knight B, Crundwell M et al. (2019). Obesity impacts the regulation of miR-10b and its targets in primary breast tumors. BMC Cancer 19: 1-0.

Meng F, Henson R, Wehbe-Janek H, Ghoshal K, Jacob ST et al. (2007). MicroRNA-21 regulates expression of the PTEN tumor suppressor gene in human hepatocellular cancer. Gastroenterology 133: 647-658.

Meng T, Shang N, Nsabimana A, Ye H, Wang H, Wang C, Zhang Y (2020). An enzyme-free electrochemical biosensor based on target-catalytic hairpin assembly and Pd@UiO-66 for the ultrasensitive detection of microRNA-21. Analytica Chimica Acta 1138: 59-68.

Mi Y, Liu F, Liang X, Liu S, Huang X et al. (2019). Tumor suppressor let-7a inhibits breast cancer cell proliferation, migration and invasion by targeting MAGE-A1. Neoplasma 66: 54-62.

Moazzeni H, Najafi A, Khani M (2017). Identification of direct target genes of miR-7, miR-9, miR-96, and miR-182 in the human breast cancer cell lines MCF-7 and MDA-MB-231. Molecular and Cellular Probes 34: 45-52.
Mu F, Huang J, Xing T, Jing Y, Cui T et al. (2019). The Wnt/ $\beta$ catenin/Lef1 pathway promotes cell proliferation at least in part through direct upregulation of miR-17-92 cluster. Frontiers in Genetics 10: 525.

Negrini M, Calin GA (2008). Breast cancer metastasis: A microRNA story. Breast Cancer Research 10: 1-4.

O'Brien J, Hayder H, Zayed Y, Peng C (2018). Overview of microRNA biogenesis, mechanisms of actions, and circulation. Frontiers in Endocrinology 9: 402.

O’Day E, Lal A (2010). MicroRNAs and their target gene networks in breast cancer. Breast Cancer Research 12: 1-0.

Pan H, Gu L, Liu B, Li Y, Wang Y et al. (2017). Tropomyosin-1 acts as a potential tumor suppressor in human oral squamous cell carcinoma. PLoS One 12: e0168900.

Petri BJ, Klinge CM (2020). Regulation of breast cancer metastasis signaling by miRNAs. Cancer and Metastasis Reviews 39: 837-886.

Powers MA, Fay MM, Factor RE, Welm AL, Ullman KS (2011). Protein arginine methyltransferase 5 accelerates tumor growth by arginine methylation of the tumor suppressor programmed cell death 4. Cancer Research 71: 5579-5587.

Qattan A, Intabli H, Alkhayal W, Eltabache C, Tweigieri T, Amer SB (2017). Robust expression of tumor suppressor miRNA's let7 and miR-195 detected in plasma of Saudi female breast cancer patients. BMC Cancer 17.

Qi L, Bart J, Tan LP, Platteel I, van der Sluis T et al. (2009). Expression of miR-21 and its targets (PTEN, PDCD4, TM1) in flat epithelial atypia of the breast in relation to ductal carcinoma in situ and invasive carcinoma. BMC Cancer 9: 1-8.

Quan D, Chen K, Zhang J, Guan Y, Yang D, Wu H, Wu S, Lv L (2020). Identification of lncRNA NEAT1/miR-21/RRM2 axis as a novel biomarker in breast cancer. Journal of Cellular Physiology 235: 3372-3381.

Rahim A, Afzal M, Naveed AK (2019). Genetic polymorphism of miRNA-196a and its target gene annexin-A1 expression based on ethnicity in Pakistani female breast cancer patients. Pakistan Journal of Medical Sciences 35: 1598.

Rastogi YR, Saini AK, Thakur VK, Saini RV (2020). New insights into molecular links between microbiota and gastrointestinal cancers: A literature review. International Journal of Molecular Sciences 9: 3212.

Rao X, Di Leva G, Li M, Fang F, Devlin C et al. (2011). MicroRNA-221/ 222 confers breast cancer fulvestrant resistance by regulating multiple signaling pathways. Oncogene 30: 1082-1097.

Reddy SD, Ohshiro K, Rayala SK, Kumar R (2008). MicroRNA-7, a homeobox D10 target, inhibits p21-activated kinase 1 and regulates its functions. Cancer Research 68: 8195-8200.

Ren YQ, Wang HJ, Zhang YQ, Liu YB (2017). WBP2 modulates G1/S transition in ER+ breast cancer cells and is a direct target of miR-206. Cancer Chemotherapy and Pharmacology 79: 1003-1011.

Rui X, Zhao H, Xiao X, Wang L, Mo L et al. (2018). MicroRNA-34a suppresses breast cancer cell proliferation and invasion by targeting Notch1. Experimental and Therapeutic Medicine 16: $4387-4392$.

Saito M, Okamoto A, Kohno T, Takakura S, Shinozaki H et al. (2000). Allelic imbalance and mutations of the PTEN gene in ovarian cancer. International Journal of Cancer 85: 160-165.

Samaeekia R, Adorno-Cruz V, Bockhorn J, Chang YF, Huang S et al. (2017). miR-206 inhibits stemness and metastasis of breast cancer by targeting MKL1/IL11 pathway. Clinical Cancer Research 23: 1091-1103.

Santolla MF, Lappano R, Cirillo F, Rigiracciolo DC, Sebastiani A et al. (2018). miR-221 stimulates breast cancer cells and 
cancer-associated fibroblasts (CAFs) through selective interference with the A20/c-Rel/CTGF signaling. Journal of Experimental \& Clinical Cancer Research 37: 1-2.

Savad S, Mehdipour P, Miryounesi M, Shirkoohi R, Fereidooni F, Mansouri F, Modarressi MH (2012). Expression analysis of MiR-21, MiR-205, and MiR-342 in breast cancer in Iran. Asian Pacific Journal of Cancer Prevention 13: 873-877.

Scott GK, Goga A, Bhaumik D, Berger CE, Sullivan CS, Benz CC (2007). Coordinate suppression of ERBB2 and ERBB3 by enforced expression of micro-RNA miR-125a or miR-125b. Journal of Biological Chemistry 282: 1479-1486.

Selcuklu SD, Donoghue MT, Spillane C (2009). miR-21 as a key regulator of oncogenic processes. Biochemical Society Transactions 37: 918-925.

Shao X, Tandon R, Samara G, Kanki H, Yano H et al. (1998). Mutational analysis of the PTEN gene in head and neck squamous cell carcinoma. International Journal of Cancer 77: 684-688.

Sheedy FJ, Palsson-McDermott E, Hennessy EJ, Martin C, O’leary JJ et al. (2010). Negative regulation of TLR4 via targeting of the proinflammatory tumor suppressor PDCD4 by the microRNA miR-21. Nature Immunology 11: 141-147.

Shen L, Wan Z, Ma Y, Wu L, Liu F et al. (2015). The clinical utility of microRNA-21 as novel biomarker for diagnosing human cancers. Tumor Biology 36: 1993-2005.

Shen M, Dong C, Ruan X, Yan W, Cao M et al. (2019). Chemotherapy-induced extracellular vesicle miRNAs promote breast cancer stemness by targeting ONECUT2. Cancer Research 79: 3608-3621.

Sheng P, Fields C, Aadland K, Wei T, Kolaczkowski O et al. (2018). Dicer cleaves 5 '-extended microRNA precursors originating from RNA polymerase II transcription start sites. Nucleic Acids Research 46: 5737-5752.

Shi L, Chen J, Yang J, Pan T, Zhang S, Wang Z (2010). MiR-21 protected human glioblastoma U87MG cells from chemotherapeutic drug temozolomide induced apoptosis by decreasing Bax/Bcl-2 ratio and caspase-3 activity. Brain Research 1352: 255-264.

Shibahara Y, Miki Y, Onodera Y, Hata S, Chan MS et al. (2012). Aromatase inhibitor treatment of breast cancer cells increases the expression of let-7f, a microRNA targeting CYP19A1. Journal of Pathology 227: 357-366.

Shimono Y, Zabala M, Cho RW, Lobo N, Dalerba P et al. (2009). Downregulation of miRNA-200c links breast cancer stem cells with normal stem cells. Cell 138: 592-603.

Si ML, Zhu S, Wu H, Lu Z, Wu F, Mo YY (2007). miR-21-mediated tumor growth. Oncogene 26: 2799-2803.

Singh P, Wedeken L, Waters LC, Carr MD, Klempnauer KH (2011). Pdcd4 directly binds the coding region of c-myb mRNA and suppresses its translation. Oncogene 30: 4864-4873.

Singh R, Mo YY (2013). Role of microRNAs in breast cancer. Cancer Biology \& Therapy 14: 201-212.

Song X, Liang Y, Sang Y, Li Y, Zhang H et al. (2020). CircHMCU promotes proliferation and metastasis of breast cancer by sponging the let-7 family. Molecular Therapy-Nucleic Acids 20: $518-533$.

Sørlie T, Tibshirani R, Parker J, Hastie T, Marron JS et al. (2003). Repeated observation of breast tumor subtypes in independent gene expression data sets. Proceedings of The National Academy of Sciences of The United States of America 100: 8418-8423.

Steiner E, Klubert D, Knutson D (2008). Assessing breast cancer risk in women. American Family Physician 78: 1361-1366.
Stoddard II FR, Brooks AD, Eskin BA, Johannes GJ (2008). Iodine alters gene expression in the MCF7 breast cancer cell line: evidence for an anti-estrogen effect of iodine. International Journal of Medical Sciences 5: 189.

Sun F, Fu H, Liu Q, Tie Y, Zhu J, Xing R, Sun Z, Zheng X (2008). Downregulation of CCND1 and CDK6 by miR-34a induces cell cycle arrest. Federation of European Biochemical Societies Letters 582: 1564-1568.

Sun X, Wang H, Jian Y, Lan F, Zhang L et al. (2018). Ultrasensitive microfluidic paper-based electrochemical/visual biosensor based on spherical-like cerium dioxide catalyst for miR-21 detection. Biosensors and Bioelectronics 105: 218-225.

Tang CP, Zhou HJ, Qin J, Luo Y, Zhang T (2017). MicroRNA-520c3 p negatively regulates EMT by targeting IL- 8 to suppress the invasion and migration of breast cancer. Oncology Reports 38: 3144-3152.

Tang J, Ahmad A, Sarkar FH (2012). The role of microRNAs in breast cancer migration, invasion and metastasis. International Journal of Molecular Sciences 13: 13414-13437.

Tang X, Tu G, Yang G, Wang X, Kang L et al. (2019). Autocrine TGF$\beta 1 / \mathrm{miR}-200 \mathrm{~s} / \mathrm{miR}-221 / \mathrm{DNMT} 3 \mathrm{~B}$ regulatory loop maintains CAF status to fuel breast cancer cell proliferation. Cancer Letters 452: 79-89.

Taplin S, Abraham L, Barlow WE, Fenton JJ, Berns EA et al. (2008). Mammography facility characteristics associated with interpretive accuracy of screening mammography. Journal of the National Cancer Institute 100: 876-887.

Tvingsholm SA, Hansen MB, Clemmensen KK, Brix DM, Rafn B et al. (2018). Let-7 microRNA controls invasion-promoting lysosomal changes via the oncogenic transcription factor myeloid zinc finger-1. Oncogenesis 7: 1-5.

Uhlmann S, Zhang JD, Schwäger A, Mannsperger H, Riazalhosseini Y et al. (2010). miR-200bc/429 cluster targets PLC $\gamma 1$ and differentially regulates proliferation and EGF-driven invasion than miR-200a/141 in breast cancer. Oncogene 29: 4297-4306.

Valastyan S, Reinhardt F, Benaich N, Calogrias D, Szász AM et al. (2009). RETRACTED: A pleiotropically acting microRNA, miR-31, inhibits breast cancer metastasis. Cell 137: 1032-1046.

van Schooneveld E, Wildiers H, Vergote I, Vermeulen PB, Dirix LY et al. (2015). Dysregulation of microRNAs in breast cancer and their potential role as prognostic and predictive biomarkers in patient management. Breast Cancer Research 17: 1-5.

Várallyay E, Burgyán J, Havelda Z (2008). MicroRNA detection by northern blotting using locked nucleic acid probes. Nature Protocols 3: 190.

Wahid F, Shehzad A, Khan T, Kim YY (2010). MicroRNAs: synthesis, mechanism, function, and recent clinical trials. Biochimica et Biophysica Acta (BBA)-Molecular Cell Research 1803: 1231-1243.

Wang H, He D, Wan K, Sheng X, Cheng H et al. (2020). In situ multiplex detection of serum exosomal microRNAs using an all-in-one biosensor for breast cancer diagnosis. Analyst 145: 3289-3296.

Wang H, Tan Z, Hu H, Liu H, Wu T et al. (2019). microRNA-21 promotes breast cancer proliferation and metastasis by targeting LZTFL1. BMC Cancer 19: 1-3.

Wang J, Guan J, Lu Z, Jin J, Cai Y, Wang C, Wang F (2015). Clinical and tumor significance of tropomyosin-1 expression levels in renal cell carcinoma. Oncology Reports 33: 1326-1334.

Wang J, Tang C, Yang C, Zheng Q, Hou Y (2019). Tropomyosin-1 functions as a tumor suppressor with respect to cell proliferation, angiogenesis and metastasis in renal cell carcinoma. Journal of Cancer 10: 2220. 
Wang L, Guo J, Wang Q, Zhou J, Xu C et al. (2014). LZTFL1 suppresses gastric cancer cell migration and invasion through regulating nuclear translocation of $\beta$-catenin. Journal of Cancer Research and Clinical Oncology 140: 1997-2008.

Wang L, Kang FB, Wang J, Yang C, He DW (2019). Downregulation of miR-205 contributes to epithelial-mesenchymal transition and invasion in triple-negative breast cancer by targeting HMGB1RAGE signaling pathway. Anti-Cancer Drugs 30: 225.

Wang JL, Sun SJ, Zhang J, Wang GN (2017). Prognostic value of circulating microRNA-21 for breast cancer: A systematic review and meta-analysis. Artificial Cells, Nanomedicine, and Biotechnology 45: 1216-1221.

Wang X, Qiu H, Tang R, Song H, Pan H et al. (2018). miR-30a inhibits epithelial-mesenchymal transition and metastasis in triple-negative breast cancer by targeting ROR1. Oncology Reports 39: 2635-2643.

Wang Y, Zhang X, Chao Z, Kung HF, Lin MC et al. (2017). MiR-34a modulates ErbB2 in breast cancer. Cell Biology International 41: 93-101.

Wei N, Liu SS, Chan KK, Ngan HY (2012). Tumour suppressive function and modulation of programmed cell death 4 (PDCD4) in ovarian cancer. PLoS One 7: e30311.

Wei Q, Chen Y, Gu YF, Zhao W (2019). Molecular characterization and functional analysis of leucine zipper transcription factor like 1 in zebrafish (Danio rerio). Frontiers in Physiology 10: 801.

Wei Q, Chen ZH, Wang L, Zhang T, Duan L et al. (2016). LZTFL1 suppresses lung tumorigenesis by maintaining differentiation of lung epithelial cells. Oncogene 35: 2655-2663.

Wei Q, Zhou W, Wang W, Gao B, Wang L, Cao J, Liu ZP (2010). Tumor-suppressive functions of leucine zipper transcription factor-like 1. Cancer Research 70: 2942-2950.

Welch C, Chen Y, Stallings RL (2007). MicroRNA-34a functions as a potential tumor suppressor by inducing apoptosis in neuroblastoma cells. Oncogene 26: 5017-5022.

Wickramasinghe NS, Manavalan TT, Dougherty SM, Riggs KA, Li Y et al. (2009). Estradiol downregulates miR-21 expression and increases miR-21 target gene expression in MCF-7 breast cancer cells. Nucleic Acids Research 37: 2584-2595.

Wilczynska A, Bushell Martin (2015). The complexity of miRNAmediated repression. Cell Death \& Differentiation 22: 22-33.

Wu L, Fan J, Belasco JG (2006). MicroRNAs direct rapid deadenylation of mRNA. Proceedings of the National Academy of Sciences of the United States of America 103: 4034-4039.

Xiang Y, Liao XH, Yao A, Qin H, Fan LJ et al. (2017). MRTF-A-miR206-WDR1 form feedback loop to regulate breast cancer cell migration. Experimental Cell Research 359: 394-404.

Xiao B, Shi X, Bai J (2019). miR-30a regulates the proliferation and invasion of breast cancer cells by targeting Snail. Oncology Letters 17: 406-413.

Yager JD, Davidson NE (2006). Estrogen carcinogenesis in breast cancer. New England Journal of Medicine 354: 270-282.

Yan GR, Xu SH, Tan ZL, Liu L, He QY (2011). Global identification of miR-373-regulated genes in breast cancer by quantitative proteomics. Proteomics 11: 912-920.

Yan L, Yu MC, Gao GL, Liang HW, Zhou XY et al. (2018). MiR-125a$5 \mathrm{p}$ functions as a tumour suppressor in breast cancer by downregulating BAP1. Journal of Cellular Biochemistry 119: 8773-8783.

Yan LX, Huang XF, Shao Q, Huang MY, Deng L et al. (2008). MicroRNA miR-21 overexpression in human breast cancer is associated with advanced clinical stage, lymph node metastasis and patient poor prognosis. RNA 14: 2348-2360.

Yang HS, Cho MH, Zakowicz H, Hegamyer G, Sonenberg N, Colburn $\mathrm{NH}$ (2004). A novel function of the MA-3 domains in transformation and translation suppressor Pdcd4 is essential for its binding to eukaryotic translation initiation factor 4A. Molecular and Cellular Biology 24: 3894-3906.

Yang LW, Wu XJ, Liang Y, Ye GQ, Che Y et al. (2020). miR-155 increases stemness and decitabine resistance in triplenegative breast cancer cells by inhibiting TSPAN5. Molecular Carcinogenesis 59: 447-461.

Yang W, Wang X, Zheng W, Li K, Liu H, Sun Y (2013). Genetic and epigenetic alterations are involved in the regulation of TPM1 in cholangiocarcinoma. International Journal of Oncology 42: 690-698.

Ye J, Xu M, Tian X, Cai S, Zeng S (2019). Research advances in the detection of miRNA. Journal of Pharmaceutical Analysis 9: 217-226.

Yu F, Yao H, Zhu P, Zhang X, Pan Q et al. (2007). let-7 regulates self renewal and tumorigenicity of breast cancer cells. Cell 131: 1109-1123.

Yu RM, Cheah YK (2017). The roles of miRNAs in human breast cancer and canine mammary tumor. Applied Cancer Research 37: 37.

Yu Z, Wang C, Wang M, Li Z, Casimiro MC et al. (2008). A cyclin D1/ microRNA 17/20 regulatory feedback loop in control of breast cancer cell proliferation. Journal of Cell Biology 182: 509-517.

Zhang HD, Jiang LH, Sun DW, Li J, Tang JH (2017). miR-30a inhibits the biological function of breast cancer cells by targeting Notch1. International Journal of Molecular Medicine 40: 1235-1242.

Zhang M (2002). The role of maspin in tumor progression and normal development, pp. 96-114. Maspin. Landes Bioscience.

Zhang W, Chen CJ, Guo GL (2018). MiR-155 promotes the proliferation and migration of breast cancer cells via targeting SOCS1 and MMP16. European Review for Medical and Pharmacological Sciences 22: 7323-7332.

Zhao J, Tao Y, Zhou Y, Qin N, Chen C et al. (2015). MicroRNA-7: A promising new target in cancer therapy. Cancer Cell International 15: 1-8.

Zhao ZL, Cai Y, Wang YY, Xia CL, Li CX et al. (2015). Effects of miRNA-21 on paclitaxel-resistance in human breast cancer cells. Zhejiang Da Xue Xue Bao. Yi Xue Ban 44: 400-409.

Zhou XL, Wang M (2015). Expression levels of survivin, Bcl-2, and KAI1 proteins in cervical cancer and their correlation with metastasis. Genetics and Molecular Research 14: 17059-17067.

Zhou Y, Wang M, Tong Y, Liu X, Zhang L et al. (2019). miR-206 promotes cancer progression by targeting full-length neurokinin-1 receptor in breast cancer. Technology in Cancer Research \& Treatment 18: 1533033819875168.

Zhu S, Si ML, Wu H, Mo YY (2007). MicroRNA-21 targets the tumor suppressor gene tropomyosin 1 (TPM1). Journal of Biological Chemistry 282: 14328-14336.

Zhu S, Wu H, Wu F, Nie D, Sheng S et al. (2008). MicroRNA-21 targets tumor suppressor genes in invasion and metastasis. Cell Research 18: 350-359.

Zong Y, Zhang Y, Sun X, Xu T, Cheng X, Qin Y (2019). miR-221/ 222 promote tumor growth and suppress apoptosis by targeting lncRNA GAS5 in breast cancer. Bioscience Reports 39: BSR20181859. 